\title{
Influence of Lightweight Aggregate Concrete Materials on Building Energy Performance
}

\author{
Tara L. Cavalline ${ }^{1, * \mathbb{C}}$, Jorge Gallegos ${ }^{2}$, Reid W. Castrodale ${ }^{3}$, Charles Freeman ${ }^{4}$, Jerry Liner ${ }^{4}$ and Jody Wall ${ }^{4}$ \\ 1 Department of Engineering Technology and Construction Management, \\ University of North Carolina at Charlotte, Charlotte, NC 28223, USA \\ 2 Shelco, LLC, Charlotte, NC 28208, USA; Jgallegos@shelcollc.com \\ 3 Castrodale Engineering Consultants, PC, Concord, NC 28025, USA; \\ reid.castrodale@castrodaleengineering.com \\ 4 Stalite, Salisbury, NC 28144, USA; cfreeman@stalite.com (C.F.); jliner@stalite.com (J.L.); \\ jwall@stalite.com (J.W.) \\ * Correspondence: tcavalline@uncc.edu; Tel.: +1-704-687-5035
}

Citation: Cavalline, T.L.; Gallegos, J.; Castrodale, R.W.; Freeman, C.; Liner, J.; Wall, J. Influence of Lightweight Aggregate Concrete Materials on Building Energy Performance. Buildings 2021, 11, 94. https:// doi.org/10.3390/buildings11030094

Academic Editors: Oliver Kinnane and Richard O'Hegarty

Received: 20 January 2021

Accepted: 24 February 2021

Published: 3 March 2021

Publisher's Note: MDPI stays neutral with regard to jurisdictional claims in published maps and institutional affiliations.

Copyright: (c) 2021 by the authors. Licensee MDPI, Basel, Switzerland. This article is an open access article distributed under the terms and conditions of the Creative Commons Attribution (CC BY) license (https:// creativecommons.org/licenses/by/ $4.0 /)$.

\begin{abstract}
Due to their porous nature, lightweight aggregates have been shown to exhibit thermal properties that are advantageous when used in building materials such as lightweight concrete, grout, mortar, and concrete masonry units. Limited data exist on the thermal properties of materials that incorporate lightweight aggregate where the pore system has not been altered, and very few studies have been performed to quantify the building energy performance of structures constructed using lightweight building materials in commonly utilized structural and building envelope components. In this study, several lightweight concrete and masonry building materials were tested to determine the thermal properties of the bulk materials, providing more accurate inputs to building energy simulation than have previously been used. These properties were used in EnergyPlus building energy simulation models for several types of commercial structures for which materials containing lightweight aggregates are an alternative commonly considered for economic and aesthetic reasons. In a simple model, use of sand lightweight concrete resulted in prediction of $15-17 \%$ heating energy savings and $10 \%$ cooling energy savings, while use of all lightweight concrete resulted in prediction of approximately $35-40 \%$ heating energy savings and 30\% cooling energy savings. In more complex EnergyPlus reference models, results indicated superior thermal performance of lightweight aggregate building materials in 48 of 50 building energy simulations. Predicted energy savings for the five models ranged from $0.2 \%$ to $6.4 \%$.
\end{abstract}

Keywords: building energy simulation; energy savings; lightweight aggregate; concrete; masonry; grout; thermal properties; heat capacity; thermal conductivity

\section{Introduction and Background \\ 1.1. Lightweight Aggregate Concrete Materials}

Manufactured lightweight aggregates are a building product produced by heating certain shales, clays, slates, fly ashes, or blast-furnace slags in a high-energy pyroprocessing facility [1]. Expansion of gases during the processing and subsequent cooling results in an expanded, highly porous, cellular aggregate that has a lower relative density than the source material. Lightweight aggregates used for structural concrete must meet the physical property requirements outlined in American Society for Testing and Materials (ASTM) C330 [2], with maximum dry loose bulk densities for lightweight fine aggregate, coarse aggregate, and combined fine and coarse aggregate limited to a maximum of $1120 \mathrm{~kg} / \mathrm{m}^{3}$ $\left(70 \mathrm{lb} / \mathrm{ft}^{3}\right), 990 \mathrm{~kg} / \mathrm{m}^{3}\left(55 \mathrm{lb} / \mathrm{ft}^{3}\right)$, and $1040 \mathrm{~kg} / \mathrm{m}^{3}\left(65 \mathrm{lb} / \mathrm{ft}^{3}\right)$ respectively.

The physical and thermal properties of different types of lightweight aggregates vary based on properties of the source material, the pyroprocessing method utilized, and other 
associated processing techniques such as cooling, crushing, and grading [3]. The performance of lightweight concrete and masonry building products will be a function of the properties of the lightweight aggregates as well as the other mixture materials and the proportions utilized, and unique to the lightweight material and mixtures used [1]. Specifically, factors affecting the thermal conductivity of concrete include "age, aggregate volume fraction, amount of cement, types of admixtures, fine aggregate fraction, temperature, and moisture status" [4]. Ultimately, studies have shown that for lightweight concrete, the aggregate type is not as influential in thermal performance as the porosity and moisture content $[5,6]$.

Thermal properties of building materials, including thermal conductivity and heat capacity, influence the building energy performance of a structure. Several publications provide suggested ranges of values for thermal properties of lightweight concrete and masonry materials. However, suggested ranges are often either (1) quite broad or (2) limited to a single value with no indication of adjustments that may be required based on local materials or mixture proportions. In many instances, details regarding material types, mixture proportions, test methods, and specimen conditioning are not provided.

For example, ASTM Selected Technical Papers (STP) 169D, Significance and Tests and Properties of Concrete and Concrete-Making Materials, provides thermal conductivity values for lightweight concrete mixtures using three types of normalweight aggregates and one type of lightweight aggregate (expanded shale) [6]. However, information on the mixture proportions used is not provided, and it is noted that these values were determined based on work performed in the 1960s, when materials and mixture proportions were somewhat different from those used in modern times (particularly for higher strength mixtures. ASTM STP 169D does not provide recommended values for heat capacity [6].

American Concrete Institute (ACI) 122, "Guide to Thermal Properties of Concrete and Masonry Systems" [7] provides calculated estimates of thermal conductivity based on density and type of material "obtained from density/thermal conductivity linear equations" based on work by Valore [8]. Similar to ASTM STP 169D, ACI 122 does not provide guidance on adjustments of these values based on mixture proportions [7]. Lightweight aggregates of many types (pumice, expanded clay, expanded shale, and expanded slate) are grouped together, with only a single thermal conductivity value suggested regardless of the type of lightweight aggregate used [7]. Although providing recommendations of specific heat of concrete, mortar, and grout based on density, ACI 122 does not provide details on the materials and mixture proportions used in identification of these values, or guidance regarding adjustment of the values for local materials or mixture proportions [7].

The American Society of Heating, Refrigerating and Air-Conditioning Engineers (ASHRAE) Handbook also provides suggested values for the thermal conductivity and heat capacity of concrete materials, broadly grouping materials by normalweight concrete (sand and gravel or stone aggregates) and lightweight aggregate concrete (expanded shale, clay, or slate, expanded slag, pumice and scoria) [9]. Values published by ASHRAE are attributed to work in the 1980s by Valore $[8,10]$ on concrete, hollow concrete masonry, and constituent materials. Similar to other publications, ranges of suggested values for thermal conductivity are quite broad, with the upper and lower suggested values for normalweight concrete varying by over 100\% [10]. Many thermal conductivity values from Valore's study published in 1980 "were estimates, calculated from concrete densities [8]," and laboratory obtained values referenced in this publication were obtained over the 50 years prior to 1980, using equipment and test methods that vary from those available today [8]. Thermal properties for normalweight and lightweight concrete blocks published in ASHRAE [8] and attributed to Valore's 1998 study [10] are provided for hollow concrete blocks, or with cores filled with perlite, vermiculite, or molded expanded polystyrene (not grout). Data is provided for thermal resistance and specific heat of concrete and masonry materials, but not thermal conductivity [9].

In summary, existing publications suggesting thermal properties for concrete/masonry materials provide little or no information on the concrete or mortar mixture proportions 
and materials, specimen preparation, or moisture state of the materials at time of testing, limiting the utility of this data for designers desiring to identify inputs for building energy simulation models. Additionally, modern materials, mixture proportions, and test methods were not used to obtain many published thermal property values. Values are generally suggested based on concrete density, and there is often a significant overlap between recommended values for different concrete densities, making it difficult for a designer to have confidence in selection of a value that represents local materials and the desired mixture proportions. A detailed summary of published thermal property values, along with additional insight into issues associated with the recommendations is provided in [11].

Additionally, the thermal conductivity of a material is often measured using ASTM C177 [12] or ASTM C1363 [13], which require crushing of the specimen to a powder. This approach destroys the void structure within building materials that incorporate lightweight aggregate, significantly altering the measured thermal properties. Very few studies on heat capacity of lightweight building materials exist in the literature, with a range of equipment types and saturation states $[14,15]$. In the study reported here, a method was used that measured the thermal conductivity and heat capacity of building materials containing lightweight aggregate that utilized intact (bulk) samples, providing more accurate values of the thermal conductivity and heat capacity of lightweight concrete and grout than used in other studies [11].

\subsection{Building Energy Simulation Models and Lightweight Aggregate Concrete Building Materials}

An urgent need exists to reduce energy use and to conserve resources, and energy simulation software is available to allow designers to compare the energy performance of building systems using different types of materials. Lightweight concrete and masonry units have been shown to provide energy savings because of their unique thermal properties that result from the porous nature of the lightweight aggregate $[5,16]$. However, as described previously, accurate measurement of thermal properties for these materials has been hampered by test methods that require crushing which significantly alters the performance of the material and hides the improvements possible from using these materials [11].

This study uses the EnergyPlus software (version 8.5.0, National Renewable Energy Laboratory, Golden, CO, USA), with input material properties measured using a new test method that preserves the void space within the building materials containing the lightweight aggregates, which provides a more accurate indication of the potential energy saving resulting from the use of lightweight concrete, grout, and masonry units in typical building construction. EnergyPlus is the official building simulation program of the United States Department of Energy (DOE), promoted through the Building and Technology Program of the Energy Efficiency and Renewable Energy Office [17]. EnergyPlus is an evolution of older DOE simulation engines and offers a simulation engine for a series of third party interfaces [18]. Funded by the DOE Building Technologies Office (BTO) and managed by the National Renewable Energy Laboratory (NREL), this software has been utilized extensively by both public and private entities to perform energy analysis and thermal load simulation for a broad range of applications including sizing of heating, ventilation, and air conditioning (HVAC) equipment, building retrofit studies, life cycle analysis (LCA) studies, energy performance optimization, and other uses. Weather data to support the simulations is available for over 2100 locations worldwide, and the open-source code utilized by the software has allowed a number of users to customize and enhance the capabilities of the program. The program is capable of modeling the heating, cooling, lighting, ventilating, and other energy flows as well as water in buildings $[19,20]$.

Building energy simulation studies quantifying energy savings from lightweight concrete materials are limited in the published literature. One study showed that lightweight aggregate concrete can reduce heat losses due to thermal bridging effects, when compared to normalweight concrete [21], although in this study thermal properties were determined using a surface measurement probe rather than measurement of bulk samples, and only 
one type of residential building (single-story apartment model) was included in this study. This study showed that lightweight concrete could contribute to the reduction of heating energy in Europe, but did not substantially contribute to a reduction in cooling energy needs [21]. A study of ultra-lightweight concrete (ULWC) evaluated the performance of this novel material (not typically used in construction currently) against buildings with greater thermal mass using EnergyPlus [22]. It was found that the ULWC could provide energy savings in some situations, with certain building configuration/operational characteristics and climate combinations showing energy savings over conventional construction, while energy savings were not predicted in other situations [22].

Research sponsored by the Portland Cement Association aimed to model the energy performance of concrete buildings to support credit in the Leadership in Energy and Environmental Design (LEED) New Construction system [23]. Energy use in mid-rise buildings was simulated using VisualDOE (Version 4.0.0, Architectural Energy Corporation, San Francisco, CA, USA) and Energy-10 (Sustainable Buildings Industry Council, Washington, DC, USA) software programs using weather data from six varying climates in the United States. In this study, the thermal performance of precast normalweight concrete walls was compared to that of structural steel or reinforced concrete frames, with the concrete materials showing advantages over other materials. Typical cold climate energy cost savings ranged from $14 \%$ to $21 \%$ [23]. It is noted that lightweight concrete was not included in this study.

A numerical (2D and 3D finite element) and laboratory study of thermal performance of a single wall system indicated significant thermal transmittance reductions (ranging from $12 \%$ to $27 \%$ ) for walls constructed of lightweight concrete masonry units, with greater thermal resistance exhibited with when lightweight mortar was used in the joints [24]. This study did not utilize the full range of capabilities of building energy simulations, however, since only a simple single wall system was included in the model.

Previously, the lead author of this study performed research that predicted energy savings in masonry structures when porous recycled aggregate from demolition waste was used in mortar [25]. This study also used EnergyPlus simulations in several United States climate regions. A single type of commercial building model (strip mall) was used in this analysis, and the recycled aggregate is not typically used in commercial building construction. However, control models using lightweight concrete masonry exhibited energy efficiency greater than that of normalweight masonry materials, particularly in warmer climates [25].

\subsection{Research Hypothesis and Significance}

The authors hypothesize that use of accurately measured thermal properties (heat capacity and thermal conductivity) for lightweight aggregate concrete materials in building energy simulation models will result in predictions of significant energy savings for commercial buildings. Due to the use of material-specific, accurately measured thermal inputs into the building energy simulation models, this research provides, perhaps for the first time, data that more accurately quantifies the potential energy savings from use of these materials in a range of commercial buildings where lightweight aggregate concrete materials are an economical and aesthetic choice of designers, in a variety of climates.

\section{Materials and Methods}

In this study, measured mechanical and thermal properties for the lightweight concrete, masonry grout, and concrete masonry units (CMUs) were utilized in selected building components in a series of commercial building models developed using the building energy simulation program EnergyPlus. Commercial building models used for this study selected because they represent a significant portion of the United States inventory of commercial buildings, and they are the types of structures for which lightweight aggregate concrete masonry and materials are of interest due to construction market factors (economic) and aesthetics. 


\subsection{Laboratory Testing}

As part of this work, three concrete mixture designs and two mortar designs were batched and tested, along with three types of concrete masonry units. Concrete mixture designs were normalweight concrete (NWC), comprised of locally available natural fine and coarse aggregates, sand lightweight concrete (SLC), containing natural sand and a lightweight coarse aggregate, and an all lightweight concrete (ALC), containing lightweight coarse aggregate and lightweight fine aggregate. Mortar mixtures batched and tested included a normalweight grout (NWG), containing natural aggregates and a lightweight grout (LWG) containing lightweight aggregates. Additionally included in this test program were a normalweight concrete masonry unit (NWU) and a lightweight concrete masonry unit (LWU).

Lightweight aggregates consisted of an expanded slate aggregate manufactured using a rotary kiln process. The properties of the lightweight aggregates vary by gradation, and a summary is presented in Table 1. For the concrete and grout mixtures, normalweight fine aggregates consisted of natural silica sands and normalweight coarse aggregates consisted of granitic gneiss. Characteristics of these aggregates are also presented in Table 1. For concrete mixtures, the aggregate gradations commonly used for building construction (American Association of State Highway and Transportation Officials \{AASHTO\} No. 67 natural coarse aggregate and $12.7 \mathrm{~mm}\left(\frac{1}{2} \mathrm{in}\right.$.) lightweight coarse aggregate) were used.

Table 1. Aggregate properties and characteristics.

\begin{tabular}{|c|c|c|c|c|}
\hline \multirow{2}{*}{ Characteristic } & \multicolumn{2}{|c|}{ Coarse Aggregates } & \multicolumn{2}{|c|}{ Fine Aggregates } \\
\hline & Normalweight & Lightweight & Normalweight & Lightweight \\
\hline Type & Granitic gneiss & Expanded slate & Natural silica sand & Expanded slate \\
\hline Gradation & $\begin{array}{l}\text { ASTM C33 [26] or } \\
\text { AASHTO \#67 [27] }\end{array}$ & $\begin{array}{c}\text { ASTM C330 [2] or } \\
\text { AASHTO M } 195 \text { [28] }\end{array}$ & ASTM C33 [26] & NCDOT 2MS [29] \\
\hline $\begin{array}{l}\text { Specific gravity (Oven } \\
\text { dry) }\end{array}$ & 2.75 & $\begin{array}{c}1.52 \\
\text { (for } 19.1 \mathrm{~mm}\{3 / 4 \mathrm{in} .\} \\
\text { nom. max. gradation) } \\
1.53 \\
\text { (for } 12.7 \mathrm{~mm}\{1 / 2 \mathrm{in} .\} \\
\text { nom. max. gradation) }\end{array}$ & 2.63 & 1.85 \\
\hline Absorption (\%) & 0.50 & $\begin{array}{c}6.0 \% \text { at } 24 \mathrm{~h} \\
\text { (for } 19.1 \mathrm{~mm}\{3 / 4 \mathrm{in} .\} \\
\text { nom. max. gradation) } \\
7.0 \% \text { at } 24 \mathrm{~h} \\
\text { (for } 12.7 \mathrm{~mm}\{1 / 2 \text { in. }\} \\
\text { nom. max. gradation) }\end{array}$ & 0.50 & 10.0 (at $24 \mathrm{~h}$ ) \\
\hline $\begin{array}{l}\text { Bulk loose unit weight, } \\
\mathrm{kg} / \mathrm{m}^{3}\left(\mathrm{lb} / \mathrm{ft}^{3}\right)\end{array}$ & $\begin{array}{l}1506 \\
(94)\end{array}$ & $\begin{array}{l}801 \\
(50)\end{array}$ & $\begin{array}{c}1474 \\
(92)\end{array}$ & $\begin{array}{l}881 \\
(55)\end{array}$ \\
\hline
\end{tabular}

Concrete mixture proportions are shown in Table 2. Cement utilized for concrete and grout mixtures was a Type I cement meeting ASTM C150 [30]. Concrete mixtures also utilized a Type F fly ash, substituted for cement at a rate of $20 \%$ by weight. Nominal amounts of an air entraining admixture, normal-range water reducing admixture, and a high-range water reducing admixture were utilized in the concrete mixtures at the dosage rates provided in Table 2 . The target slump was $152.4 \mathrm{~mm}$ ( 6 in.). The water to cementitious materials ratio $(\mathrm{w} / \mathrm{cm})$ for all concrete mixtures was 0.41 . Grout mixtures produced for the testing program are also shown in Table 2. Concrete masonry units utilized for the testing program included three types: a normalweight CMU (NWU) with a unit weight of $2002 \mathrm{~kg} / \mathrm{m}^{3}\left(125.0 \mathrm{lb} / \mathrm{ft}^{3}\right)$, a lightweight concrete masonry unit (LWU) with a unit weight of $1672 \mathrm{~kg} / \mathrm{m}^{3}\left(104.4 \mathrm{lb} / \mathrm{ft}^{3}\right)$, and a lightweight concrete masonry unit (LWU) with a unit weight of $1482 \mathrm{~kg} / \mathrm{m}^{3}\left(92.5 \mathrm{lb} / \mathrm{ft}^{3}\right)$. 
Table 2. Concrete and grout mixture proportions.

\begin{tabular}{|c|c|c|c|c|c|}
\hline \multirow[b]{2}{*}{ Mixture Component / Test } & \multicolumn{3}{|c|}{ Concrete Mixtures } & \multicolumn{2}{|c|}{ Grout Mixtures } \\
\hline & $\begin{array}{l}\text { Normalweight } \\
\text { (NWC) }\end{array}$ & $\begin{array}{l}\text { Sand Lightweight } \\
\text { (SLC) }\end{array}$ & $\begin{array}{l}\text { All Lightweight } \\
\text { (ALC) }\end{array}$ & $\begin{array}{l}\text { Normalweight } \\
\text { Grout (NWG) }\end{array}$ & $\begin{array}{l}\text { Lightweight } \\
\text { Grout (LWG) }\end{array}$ \\
\hline \multicolumn{6}{|l|}{ Mixture components } \\
\hline Cement, type I, kg/m³, (lb/cy) & $347.7(586)$ & $347.7(586)$ & $347.7(586)$ & $406.4(685)$ & $406.4(685)$ \\
\hline Fly ash, $\mathrm{kg} / \mathrm{m}^{3}$ (lb/cy) & $86.6(146)$ & $86.6(146)$ & $86.6(146)$ & $0(0)$ & $0(0)$ \\
\hline $\begin{array}{l}\text { Natural fine aggregate, } \mathrm{kg} / \mathrm{m}^{3} \\
(\mathrm{lb} / \mathrm{cy})\end{array}$ & 715.5 (1206) & $726.2(1224)$ & $0(0)$ & $1559(2628)$ & $0(0)$ \\
\hline $\begin{array}{l}\text { Lightweight fine aggregate, } \\
\mathrm{kg} / \mathrm{m}^{3}(\mathrm{lb} / \mathrm{cy})\end{array}$ & $0(0)$ & $0(0)$ & $510.8(861)$ & $0(0)$ & 1079 (1818) \\
\hline $\begin{array}{l}\text { AASHTO No. } 67 \text { natural coarse } \\
\text { aggregate, } \mathrm{kg} / \mathrm{m}^{3}(\mathrm{lb} / \mathrm{cy})\end{array}$ & $1115(1880)$ & $0(0)$ & $0(0)$ & $0(0)$ & $0(0)$ \\
\hline $\begin{array}{l}\frac{1}{2} \text { in. lightweight coarse } \\
\text { aggregate, } \mathrm{kg} / \mathrm{m}^{3}(\mathrm{lb} / \mathrm{cy})\end{array}$ & $0(0)$ & $726.2(1224)$ & $569.5(960)$ & $0(0)$ & $0(0)$ \\
\hline Water, $\mathrm{kg} / \mathrm{m}^{3}$ (lb/cy) & $178.0(300)$ & $178.0(300)$ & $178.0(300)$ & $217.7(367)$ & $217.7(367)$ \\
\hline \multicolumn{6}{|l|}{ Test results } \\
\hline Air content $(\%)$ & 1.5 & 2.3 & 3.2 & 4.0 & 2.0 \\
\hline Slump, mm (in) & $184(7.25)$ & $241(9.5)$ & $247(9.75)$ & $200(8)$ & $200(8)$ \\
\hline Fresh density, $\mathrm{kg} / \mathrm{m}^{3}\left(\mathrm{lb} / \mathrm{ft}^{3}\right)$ & $2310(144.2)$ & $1991(124.3)$ & $1749(109.2)$ & $2108(131.6)$ & $1737(107.9)$ \\
\hline $\begin{array}{l}\text { Equilibrium density, } \mathrm{kg} / \mathrm{m}^{3} \\
\qquad\left(\mathrm{lb} / \mathrm{ft}^{3}\right)\end{array}$ & $\begin{array}{l}2481.3 \\
(154.9)\end{array}$ & $\begin{array}{l}1981.3 \\
(123.6)\end{array}$ & $\begin{array}{l}1709.2 \\
(106.7)\end{array}$ & $\begin{array}{c}1967 \\
(122.9)\end{array}$ & $\begin{array}{l}1434 \\
(89.6)\end{array}$ \\
\hline $\begin{array}{l}\text { Compressive strength at } 7 \text { days, } \\
\text { MPa (psi) }\end{array}$ & $41.5(6015)$ & $51.2(7430)$ & $32.7(4745)$ & $15.2(2207)$ & $14.2(2063)$ \\
\hline $\begin{array}{l}\text { Compressive strength at } 28 \\
\text { days, MPa (psi) }\end{array}$ & $55.4(8040)$ & $65.4(9480)$ & 45.5 (6605) & $25.2(3652)$ & $28.2(4084)$ \\
\hline
\end{tabular}

Batching of concrete and grout was performed in accordance with ASTM C685, "Standard Specification for Concrete Made by Volumetric Batching and Continuous Mixing" [31] Specimens were prepared in general accordance with ASTM C192, "Standard Practice for Making and Curing Concrete Test Specimens in the Laboratory" [32]. Specimens were cast from each of the mixtures and were cured indoors in laboratory conditions prior to demolding. After demolding, specimens were cured in general accordance with ASTM C192, stored in a $100 \%$ humidity room for the appropriate time period prior to testing. Laboratory testing was performed on concrete and grout mixtures in accordance with the testing protocols listed in Table 3. The age(s) of the concrete and mortar at the days of testing are also shown in Table 3. Test results for hardened concrete properties shown in Table 2 are the average of three specimens. Additional details on other tests performed is presented in Cavalline et al. [11].

Table 3. Laboratory testing program.

\begin{tabular}{ccccc}
\hline & Test & Protocol & Age(s) in Days & Replicates \\
\hline \multirow{3}{*}{ Fresh } & Air content & ASTM C231 [33] (NW, & Fresh & 1 test \\
& NWG), ASTM C173 [34] & & \\
& Slump & ASTM C143 [35] & Fresh & 1 \\
\cline { 2 - 5 } & Fresh density (unit weight) & ASTM C138 [36] & Fresh & 3 each age \\
\cline { 2 - 5 } Hardened & Compressive strength & ASTM C39 [37] & 7, 28 & 3 \\
\cline { 2 - 5 } & Heat capacity & ASTM C518 [38] & 120 days after 28 day cure & 120 days after 28 day cure \\
\cline { 2 - 5 } & Thermal conductivity & ASTM C518 [38] & &
\end{tabular}


After specimens were cured in a moist room conforming to ASTM C511 [39], compressive strength tests were performed in accordance with the standards listed in Table 2. For each of these tests, the average value for the specimens tested for each mixture is reported in Table 2. Compressive strength test results at other ages, as well as test results for other mechanical properties, are presented in Cavalline et al. [11]. Of note, the SLC concrete mixture had a greater compressive strength than the NWC concrete mixture, likely due to the slightly smaller sizes of coarse aggregate included in the $\frac{1}{2} \mathrm{in}$. lightweight coarse aggregate gradation, compared to the aggregate sizes included in the AASHTO No. 67 gradation normalweight coarse aggregate gradation commonly utilized in building construction. The larger surface area of this smaller gradation likely increased the influence of paste on the concrete strength.

Thermal conductivity and heat capacity tests were performed using the Fox50 Heat Flow Meter Instrument by TA Instruments (New Castle, DE, USA) in accordance to ASTM C518, "Standard Test Method for Steady-State Thermal Transmission Properties by Means of the Heat Flow Meter Apparatus" [38]. Three specimens were tested for each mixture, and specimens were prepared from a $101.6 \mathrm{~mm}$ (4 in.) diameter by $203.2 \mathrm{~mm}(8 \mathrm{in}$.) long cylinder. Three representative rectangular prisms approximately $38.1 \mathrm{~mm}$ by $38.1 \mathrm{~mm}$ by $25.4 \mathrm{~mm}$ thick ( $1.5 \mathrm{in}$. by $1.5 \mathrm{in}$. by $1 \mathrm{in}$.) were sawcut from the cylinder 7 days before the test date. Care was taken during sawcutting to ensure that each of the three specimens did not contain entrapped air voids and represented the mixture composition (aggregates were well distributed within the paste). Several test specimens are shown in Figure 1.

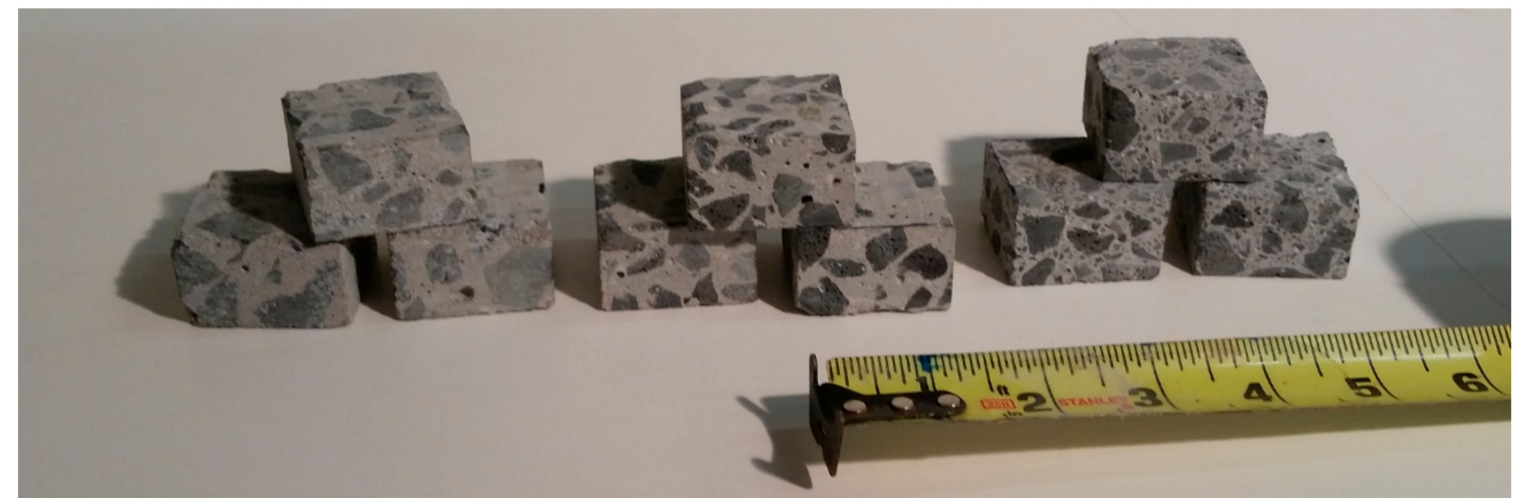

Figure 1. Concrete test specimens utilized for heat capacity and thermal conductivity testing: NWC (left), LWC (center), ALC (right).

To ensure a consistent moisture content in each specimen, the three specimens were placed into an environmental chamber set at $22.2^{\circ} \mathrm{C}\left(72{ }^{\circ} \mathrm{F}\right)$ and $50 \%$ relative humidity for seven days prior to testing. The Fox50 test apparatus utilizes software called WinTherm 32 (TA Instruments, New Castle, DE, USA) to control calibration and testing, and the calibration sequence was performed using a manufacturer supplied reference sample prior to the testing. The exact thickness of each specimen is computed by the Fox50 apparatus, and the test results provided by the equipment include adjustments for specimen height. Manufacturer supplied pads are used to cushion the specimens in the test chamber and to ensure optimal contact for the heating elements and sensors. Test values were obtained for both thermal conductivity and heat capacity at $25^{\circ} \mathrm{C}\left(77^{\circ} \mathrm{F}\right)$. Values were adjusted to account for the thermal characteristics for the cushioning pads and parchment paper used to protect the sensor coatings per the equipment manufacturer's instructions.

\subsection{Building Energy Simulations-Concrete}

Thermal properties obtained for the NWC, SLC, and ALC concrete mixtures were used in an EnergyPlus building energy simulation model to analyze the heating and cooling energy requirements of a simple structure subjected to temperatures typical of summer and winter days in selected locations. The basic model that was modified to facilitate this 
analysis is a rectangular single-story building with windows located in the east and west walls. The structure had no interior partitions, comprising a single heating/cooling zone. A schematic of the building is shown in Figure 2. In the original model used, the structure walls were defined as lightweight construction. For simulations evaluating the thermal performance of the NWC, SLC, and ALC concrete, the model was modified to include $30.5 \mathrm{~cm}$ ( $1 \mathrm{foot})$ thick concrete walls, roof and floor slab. The simulation was performed using the three different types of concrete walls, with material input characteristics for thermal conductivity, specific heat (heat capacity by weight), and unit weight as determined by testing of the NWC, SLC, and ALC mixtures. Only the inputs for thermal conductivity, specific heat, and unit weight were changed in the models to reflect the laboratory measured values, and the wall thickness of $30.5 \mathrm{~cm}$ ( 1 foot) was held constant.

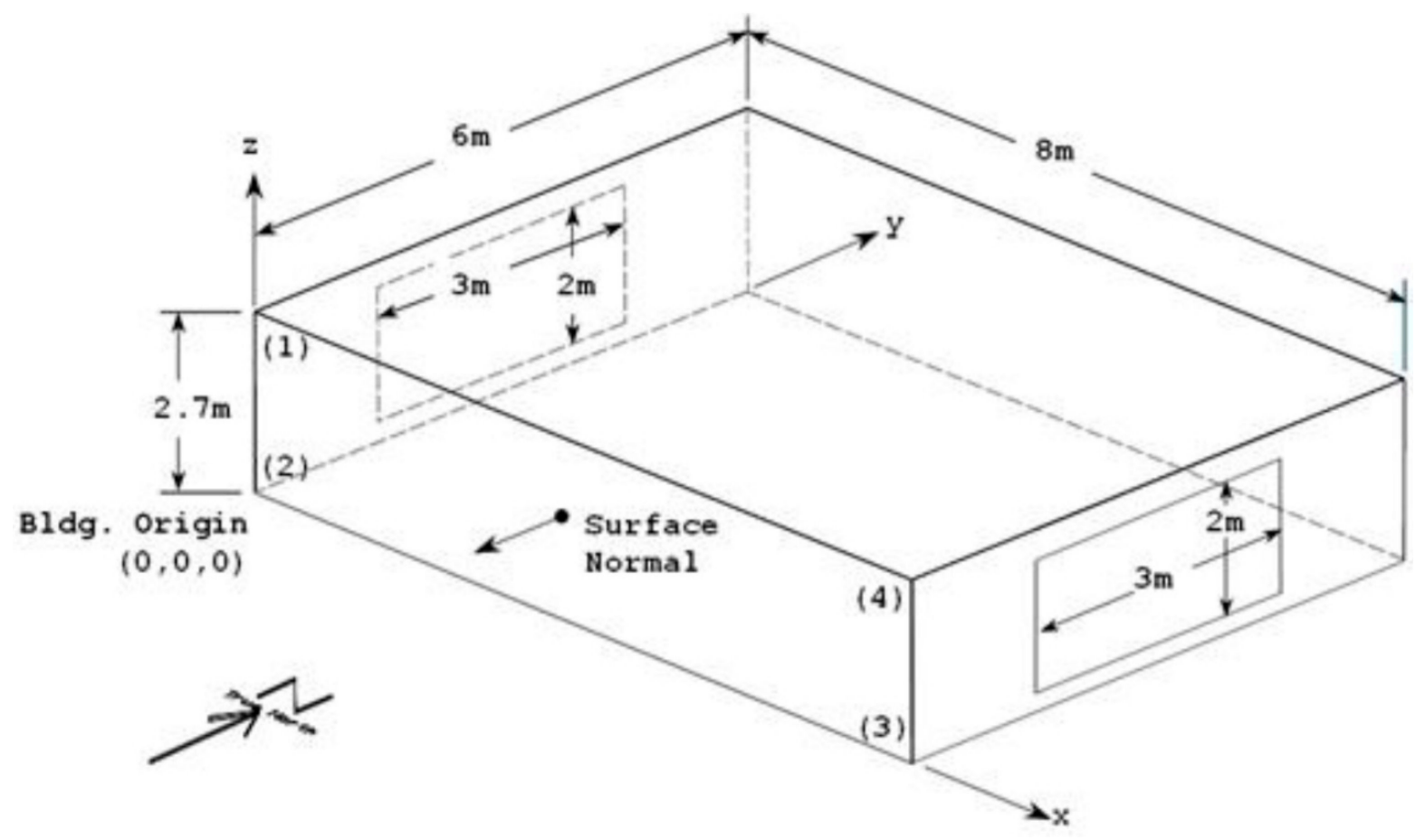

Figure 2. Schematic of simple structure used for analysis (from basic tutorial example prepared by U. of Illinois and U. of California [20]).

For this project, the default exposure conditions for the tutorial model were allowed to remain unchanged: country terrain, full interior and exterior solar distribution, full sun/wind exposure on walls and roof, and no sun/wind exposure on the floor. The HVAC defaults were also allowed to remain unchanged. In this simulation, the HVAC system is modeled as an ideal system, which mixes zone air with a specified amount of outdoor air. The ideal system also adds/removes heat and moisture at $100 \%$ efficiency to meet the specified controls. Other parameters of the reference model (such as HVAC components, air exchange parameters, building construction details, and location characteristics) were also allowed to remain constant as EnergyPlus default settings.

Weather conditions that were provided as the default design day inputs for Chicago, Illinois were utilized for the first set of simulations. Temperatures representative of a summer design day and a winter design day were utilized, as suggested by EnergyPlus. The Chicago, Illinois summer design day has a maximum dry-bulb temperature of $32.8^{\circ} \mathrm{C}$ $\left(91.0^{\circ} \mathrm{F}\right)$ with a daily dry-bulb temperature range of $10.9^{\circ} \mathrm{C}\left(51.6^{\circ} \mathrm{F}\right)$. The winter design day dry-bulb temperature was $-21.2^{\circ} \mathrm{C}\left(-6.2^{\circ} \mathrm{F}\right)$, which was held constant during the day. For a second set of simulations, temperatures representative of a warmer location were entered. For the summer design day, the maximum daily dry-bulb temperature was set to $40^{\circ} \mathrm{C}\left(104.0^{\circ} \mathrm{F}\right)$ and the daily dry-bulb temperature range was set to $15^{\circ} \mathrm{C}\left(59^{\circ} \mathrm{F}\right)$. For 
the winter design day, the maximum dry-bulb temperature was set to $15^{\circ} \mathrm{C}\left(59^{\circ} \mathrm{F}\right)$ with a daily dry-bulb temperature range of $5^{\circ} \mathrm{C}\left(9^{\circ} \mathrm{F}\right)$. For both sets of simulations, ground temperatures were allowed to remain at default values, which ranged from $18.2{ }^{\circ} \mathrm{C}$ to $22.5^{\circ} \mathrm{C}\left(64.8^{\circ} \mathrm{F}\right.$ to $\left.72.5^{\circ} \mathrm{F}\right)$, varying over the colder and warmer months.

\subsection{Building Energy Simulations-Masonry}

In this part of the study, thermal characteristics of lightweight concrete masonry materials determined in this work were used in more complex building energy models. The EnergyPlus software contains a number of reference model buildings that incorporate commonly utilized configurations and construction details. These reference buildings are detailed in Thornton et al. [40], and files supporting these reference buildings are available to the public through the EnergyPlus website. For this study, energy simulations were applied to five building models for which building materials containing lightweight aggregates are an alternative commonly considered by designers for economic and aesthetic reasons. The five building models utilized in this study were: secondary school, strip mall, midrise apartment, small hotel, and a supermarket.

Within EnergyPlus, these reference model buildings have a predetermined footprint, configuration, and story height. Details for these models are shown in Table 4, with images provided in Figure 3a-e. The space type for the secondary school, supermarket, and strip mall was non-residential, while the midrise apartment building and small hotel are residential. All five buildings have built-up flat roofs with insulation entirely above the roof deck (IEAD). The wall types for the secondary school, midrise apartment building, small hotel, and strip mall are steel frame; the wall type for the small hotel is conventional normalweight masonry. Supporting information for the reference model buildings, and the default characteristics and settings of each reference model, is provided in Field et al. [41], Thornton et al. [40] and on the Office of Energy Efficiency and Renewable Energy's website [42].

Table 4. Reference model buildings and details (from Field et al. [41]).

\begin{tabular}{|c|c|c|c|c|c|c|}
\hline $\begin{array}{l}\text { Reference } \\
\text { Model } \\
\text { Building }\end{array}$ & $\begin{array}{l}\text { Number of } \\
\text { Floors }\end{array}$ & $\begin{array}{c}\text { Floor Area, } \mathrm{m}^{2} \\
\qquad\left(\mathrm{ft}^{2}\right)\end{array}$ & Window Type & $\begin{array}{c}\text { HVAC } \\
\text { Type-Heating }\end{array}$ & $\begin{array}{c}\text { HVAC } \\
\text { Type-Cooling }\end{array}$ & Airside \\
\hline $\begin{array}{l}\text { Secondary } \\
\text { school }\end{array}$ & 2 & $\begin{array}{c}19,592 \\
(210,887)\end{array}$ & Fixed & Boiler & $\begin{array}{l}\text { Chiller, } \\
\text { air-cooled }\end{array}$ & $\begin{array}{l}\text { Single zone and } \\
\text { multi-zone } \\
\text { constant air } \\
\text { volume }\end{array}$ \\
\hline $\begin{array}{l}\text { Midrise } \\
\text { apartment } \\
\text { building }\end{array}$ & 4 & $\begin{array}{c}3135 \\
(33,740)\end{array}$ & Operable & Furnace & $\begin{array}{l}\text { Packaged direct } \\
\text { expansion split } \\
\text { system }\end{array}$ & $\begin{array}{l}\text { Single zone } \\
\text { constant air } \\
\text { volume }\end{array}$ \\
\hline Small hotel & 4 & $\begin{array}{c}4013 \\
(43,200)\end{array}$ & $\begin{array}{l}\text { Operable in } \\
\text { guest rooms, } \\
\text { others fixed }\end{array}$ & $\begin{array}{l}\text { Gas furnace } \\
\text { and electric } \\
\text { heating }\end{array}$ & $\begin{array}{c}\text { Packaged direct } \\
\text { expansion AC } \\
\text { and packaged } \\
\text { terminal AC } \\
\text { units }\end{array}$ & $\begin{array}{l}\text { Single zone } \\
\text { constant air } \\
\text { volume }\end{array}$ \\
\hline Supermarket & 1 & $\begin{array}{c}4181 \\
(45,000)\end{array}$ & Fixed & Furnace & $\begin{array}{l}\text { Packaged direct } \\
\text { expansion }\end{array}$ & $\begin{array}{l}\text { Multi-zone } \\
\text { constant air } \\
\text { volume }\end{array}$ \\
\hline Strip mall & 1 & $\begin{array}{c}2090 \\
(22,500)\end{array}$ & Fixed & Furnace & $\begin{array}{l}\text { Packaged direct } \\
\text { expansion }\end{array}$ & $\begin{array}{l}\text { Single zone } \\
\text { constant air } \\
\text { volume }\end{array}$ \\
\hline
\end{tabular}




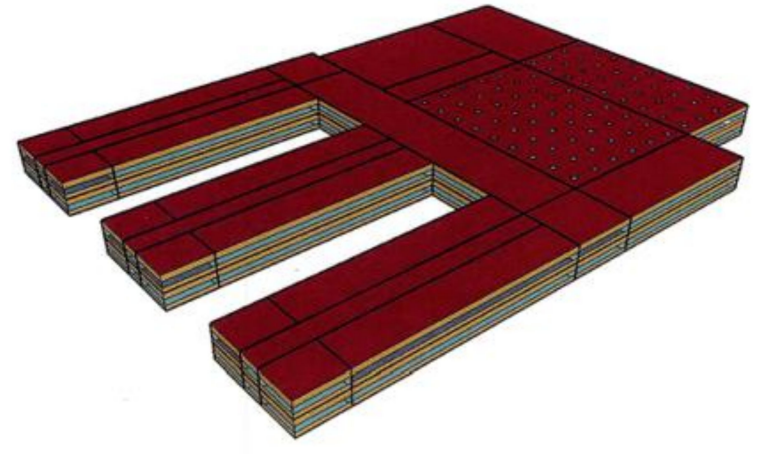

(a) Secondary school

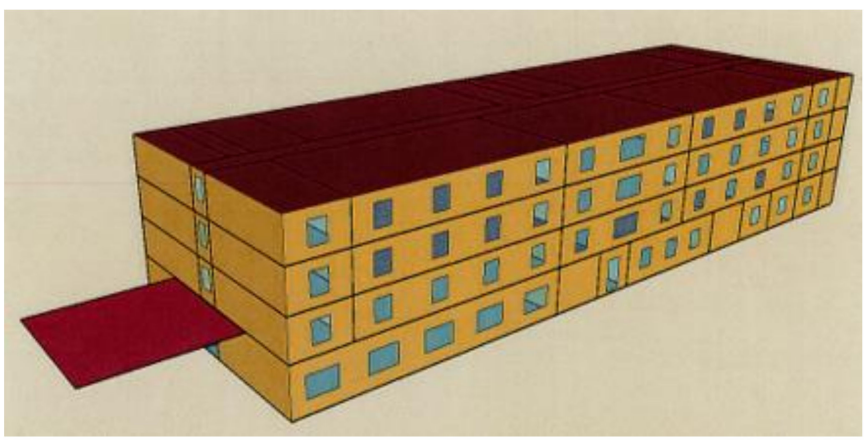

(c) Small hotel.

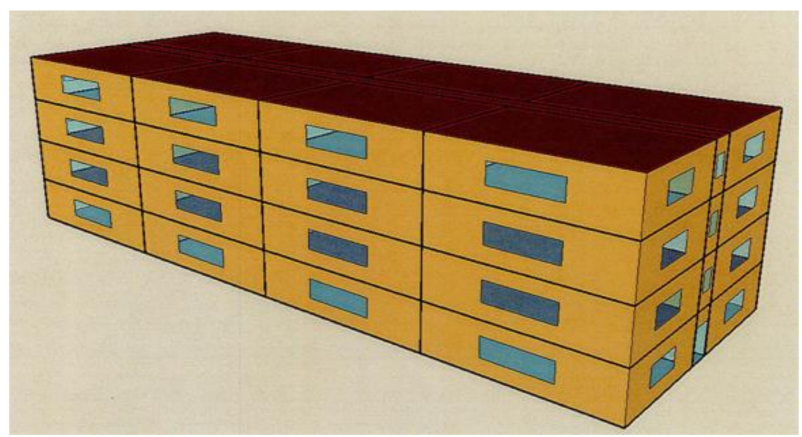

(b) Midrise apartment building

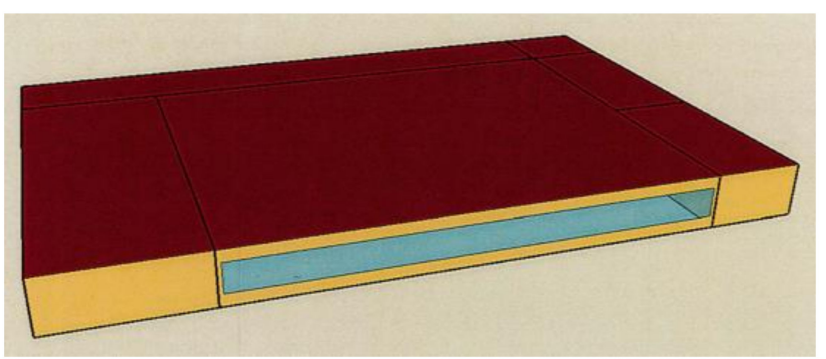

(d) Supermarket.

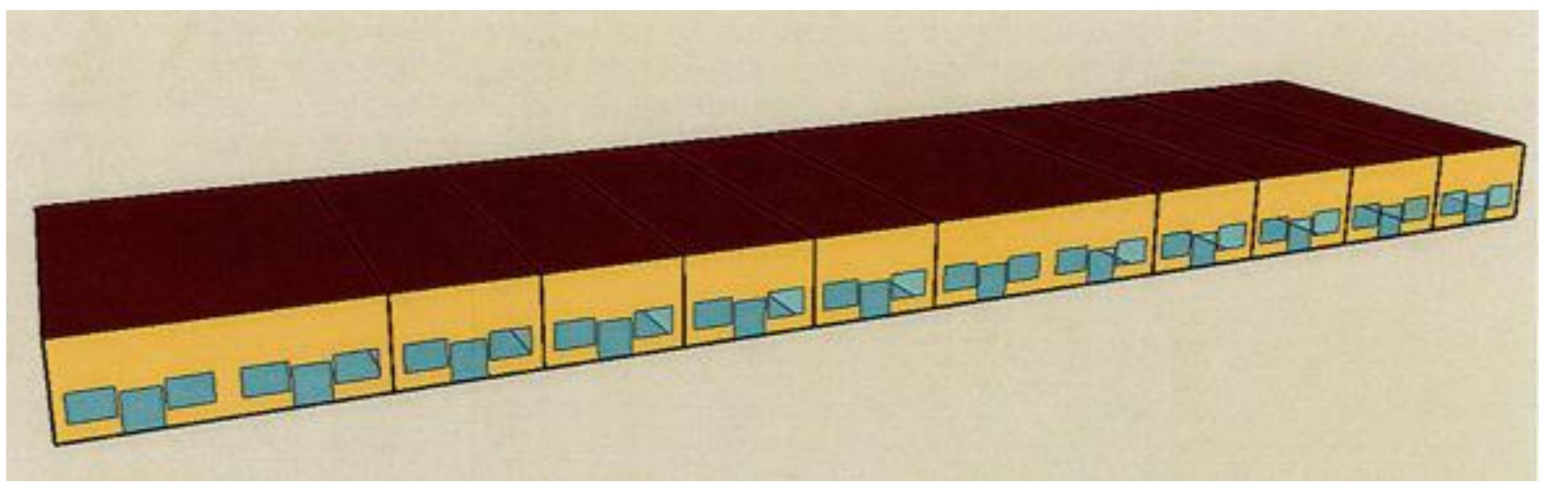

(e) Strip mall.

Figure 3. Schematics of reference model buildings used in EnergyPlus simulations (from Thornton et al. [40]).

Each building model was subjected to energy simulations using weather data from the EnergyPlus weather database for five locations, selected as sites in a diverse range of climatic conditions. These five locations are listed in Table 5, along with their outdoor air drybulb temperatures from the EnergyPlus weather database.

The four locations in the United States were selected due to their diverse climate and weather conditions, as well as their use of the specific lightweight aggregate products included in the laboratory testing portion of this work. Saudi Arabia has recently shown interest in use of the lightweight aggregate products included in the laboratory portion of this work, and was therefore selected for inclusion in this study. Additional information regarding the climatic and weather conditions for each location is provided in the EnergyPlus software [43]. 
Table 5. Locations utilized for building energy simulations with EnergyPlus reference buildings.

\begin{tabular}{|c|c|c|c|}
\hline \multirow{2}{*}{ Location } & \multirow{2}{*}{$\begin{array}{l}\text { US Climate Zone } \\
\text { and Description }\end{array}$} & \multicolumn{2}{|c|}{ Outdoor Air Drybulb Temperature, ${ }^{\circ} \mathrm{C}\left({ }^{\circ} \mathrm{F}\right)$} \\
\hline & & Summer Design Day & Winter Design Day \\
\hline Chicago & $\begin{array}{c}5 \mathrm{~A} \\
\begin{array}{c}\text { Cool temperatures } \\
\text { and humid }\end{array}\end{array}$ & $25.5(77.9)$ & $-16.6(2.1)$ \\
\hline Minneapolis & $\begin{array}{c}6 \mathrm{~A} \\
\begin{array}{c}\text { Cold temperatures } \\
\text { and humid }\end{array}\end{array}$ & $27.5(81.5)$ & $-22(-7.6)$ \\
\hline Philadelphia & $\begin{array}{c}4 \mathrm{~A} \\
\text { Mixed temperatures } \\
\text { (hot to cold) and } \\
\text { humid }\end{array}$ & $29(84.2)$ & $-8.4(16.9)$ \\
\hline Nashville & $\begin{array}{c}4 \mathrm{~A} \\
\text { Mixed temperatures } \\
\text { (hot to cold) and } \\
\text { humid }\end{array}$ & $29.2(84.6)$ & $-7.6(18.3)$ \\
\hline Saudi Arabia & $\begin{array}{c}\mathrm{N} / \mathrm{A} \\
\text { Warm to hot } \\
\text { temperatures and } \\
\text { arid }\end{array}$ & $37.0(98.6)$ & $7.2(45.0)$ \\
\hline
\end{tabular}

Using the five selected new construction reference building models, a series of building energy simulations were performed to further evaluate the impact of using building materials containing lightweight aggregates on the predicted heating and cooling energy utilized by these types of structures in several types of climates. For each simulation, the characteristics of building materials for selected components of the building envelope were changed to reflect the measured properties listed in Tables 2 and 4.

Building energy simulations were performed for each reference building type using two construction alternatives. The first, considered the base option, was the reference model which included the predetermined (typical) building characteristics established by the DOE for each reference building. The second (alternate) option included the reference model with selected building exterior components comprised of building materials containing lightweight aggregate. The alternate building exteriors were selected based upon the typical construction alternatives often considered for use in these types of construction for economic and aesthetic reasons. A summary of these base and alternate construction models is provided in Table 6. It is noted that the secondary school alternative construction type includes normalweight masonry units with normalweight grout, as is standard design practice in the United States.

Table 6. Typical and alternate building materials utilized for reference models in building energy simulations.

\begin{tabular}{|c|c|c|}
\hline $\begin{array}{l}\text { EnergyPlus Reference } \\
\text { Model Building }\end{array}$ & $\begin{array}{l}\text { Typical Exterior } \\
\text { (Field et al. [41]) }\end{array}$ & $\begin{array}{c}\text { Alternate Building } \\
\text { Framing/Material Exterior }\end{array}$ \\
\hline Midrise Apartment & Wood Siding & $\begin{array}{c}\text { LWU, } 1672 \mathrm{~kg} / \mathrm{m}^{3}\left(104.4 \mathrm{lb} / \mathrm{ft}^{3}\right) \\
\text { with lightweight grout }\end{array}$ \\
\hline Secondary School & Wood Siding & NWU with normal weight grout \\
\hline Small Hotel & Wood Siding & $\begin{array}{c}\mathrm{LWU}, 1482 \mathrm{~kg} / \mathrm{m}^{3}\left(92.5 \mathrm{lb} / \mathrm{ft}^{3}\right) \\
\text { with lightweight grout }\end{array}$ \\
\hline Strip Mall & Wood Siding & $\begin{array}{c}\mathrm{LWU}, 1672 \mathrm{~kg} / \mathrm{m}^{3}\left(104.4 \mathrm{lb} / \mathrm{ft}^{3}\right) \\
\text { with lightweight grout }\end{array}$ \\
\hline Supermarket & $\begin{array}{l}2.54 \mathrm{~cm} \text { (1 in.) Stucco w/20.3 } \\
\mathrm{cm}(8 \text { in.) normalweight CMU }\end{array}$ & $\begin{array}{c}\mathrm{LWU}, 1672 \mathrm{~kg} / \mathrm{m}^{3}\left(104.4 \mathrm{lb} / \mathrm{ft}^{3}\right) \\
\text { with lightweight grout }\end{array}$ \\
\hline
\end{tabular}


To adapt each model's default exterior construction to the alternate building framing and material exterior, the default input parameters (geometry, material properties) were changed to those specific to the alternative construction. Specifically, US standard sized CMU units with nominal length $\times$ width $\times$ thickness dimensions of $40.64 \mathrm{~cm} \times 20.32 \mathrm{~cm} \times$ $20.32 \mathrm{~cm}$ (16 in. $\times 8$ in. $\times 8$ in.) and faceshell thicknesses of $3.81 \mathrm{~cm}(1.5 \mathrm{in}$.) were assumed. These block units were assumed to have three webs: two exterior webs, plus one web in the center of the block equally dividing the two cores.

For the midrise apartment, secondary school, small hotel, and strip mall, the inputs for "wood siding" (plus insulation) exterior thickness were changed to the thickness $(20.32 \mathrm{~cm}$ or 8 in.) of LWU or NWU block. For the supermarket model, the exterior stucco and normalweight CMU default inputs (thickness) were changed to $20.32 \mathrm{~cm}$ (8 in.) for use of the LWU alone without stucco.

For all models, it was assumed that the alternate building framing/material exterior would be fully grouted CMU construction. Therefore, the thickness of each masonry wall would consist of two faceshells of the CMU, $3.81 \mathrm{~cm} \times 2=7.62 \mathrm{~cm}(1.5 \mathrm{in} . \times 2=3 \mathrm{in}$.) with the $12.7 \mathrm{~cm}$ (5 in.) thick cell between the face shells filled with grout. Using these relative proportions, a weighted average of the measured thermal conductivity, and specific heat of the appropriate grout and CMU were computed and used as inputs to the models. In a similar fashion, a weighted average of the unit weight of the grouted CMU alternate construction was computed. The weighted average of a grouted CMU accounted for the two faceshells and three webs of each standard CMU block, and assumed that the two cores of each block were fully grouted.

Other inputs and characteristics of the reference models were unchanged from the default settings, including the HVAC system components and operating characteristics, site layout and exposure conditions, characteristics of materials not used as an alternative for lightweight aggregate buildings materials (such as windows, doors, and timber/metal components) and concrete material properties not listed in Tables 2 and 4.

\section{Results and Discussion}

\subsection{Laboratory Testing of Thermal Properties}

Results from the thermal property testing are shown in Table 7, where the average value for the nine test specimens is reported. Additional information on the thermal property testing, including ranges of test results for each mixture and a detailed discussion of the results is presented in Cavalline et al. [11]. Laboratory testing performed as part of this work resulted in identification of mixture and material-specific thermal property values for thermal conductivity and heat capacity. These values were determined without crushing the void system of the lightweight aggregates contained in the concrete and masonry, and are therefore much more useful to a designer than the wide range of values found in published literature.

Test results indicated a significant change in thermal conductivity of building materials containing lightweight aggregates. Thermal conductivity tests of concrete mixtures indicated a $33.5 \%$ reduction for sand lightweight concrete (SLC) and a $65.9 \%$ reduction for all lightweight concrete (ALC) mixtures compared to the conventional normalweight concrete mixture (NWC). For grout mixtures, a $60.7 \%$ reduction in thermal conductivity was measured for the lightweight grout (LWG), compared to that of the normalweight grout (NWG) mixture. For concrete masonry units, the $1672 \mathrm{~kg} / \mathrm{m}^{3}\left(104.4 \mathrm{lb} / \mathrm{ft}^{3}\right) \mathrm{LWU}$ and $1482 \mathrm{~kg} / \mathrm{m}^{3}\left(92.5 \mathrm{lb} / \mathrm{ft}^{3}\right)$ LWU exhibited reductions in thermal conductivity of $12.0 \%$ and $33.2 \%$, respectively, from the normalweight concrete unit (NWU). The reduction in volumetric heat capacity for sand lightweight concrete (SLC) and all lightweight concrete (ALC) was measured to be $16.8 \%$ and $26.2 \%$, respectively, when compared to the normalweight concrete (NWC). Computed on a weight basis, the heat capacities of the sand lightweight (SLC) and all lightweight (ALC) concrete increased by $4.2 \%$ and $6.8 \%$ respectively, from that of the normalweight concrete (NWC). 
Table 7. Summary of thermal test results.

\begin{tabular}{|c|c|c|c|c|c|c|c|}
\hline Material & $\begin{array}{l}\text { Mixture/Material } \\
\text { Type Designation }\end{array}$ & $\begin{array}{c}\text { Thermal } \\
\text { Conductivity, } \\
\text { W/m } \cdot \mathbf{K}, \\
\left(\mathrm{BTU} /\left(\mathrm{ft} \cdot \mathbf{h r} \cdot{ }^{\circ} \mathrm{F}\right)\right)\end{array}$ & $\begin{array}{l}\text { \% Difference, } \\
\text { Compared to } \\
\text { NW Material } \\
\text { in Group }\end{array}$ & $\begin{array}{c}\text { Heat Capacity } \\
\text { (Volumetric), } \\
\mathrm{J}^{\prime} \mathrm{m}^{3} \cdot \mathrm{K}, \\
\left(\mathrm{BTU} / \mathrm{ft}^{3} \cdot{ }^{\circ} \mathrm{F}\right)\end{array}$ & $\begin{array}{c}\% \text { Differ- } \\
\text { ence, } \\
\text { Compared } \\
\text { to NWC }\end{array}$ & $\begin{array}{c}\text { Heat Capacity } \\
\text { (by Weight), } \\
\text { J/kg } \cdot \text { K, } \\
\left(\text { BTU } / \mathbf{l b} \cdot{ }^{\circ} \mathrm{F}\right)\end{array}$ & $\begin{array}{l}\text { \% Difference, } \\
\text { Compared to } \\
\text { NW Material } \\
\text { in Group }\end{array}$ \\
\hline \multirow{3}{*}{ Concrete } & NWC & $\begin{array}{c}2.116 \\
(1.223)\end{array}$ & - & $\begin{array}{c}1,910,000 \\
(28.55)\end{array}$ & - & $\begin{array}{c}771.3 \\
(0.184)\end{array}$ & - \\
\hline & SWC & $\begin{array}{c}1.408 \\
(0.814)\end{array}$ & -33.5 & $\begin{array}{c}1,590,000 \\
(23.77) \\
\end{array}$ & -16.8 & $\begin{array}{l}804.0 \\
(0.192)\end{array}$ & +4.2 \\
\hline & ALC & $\begin{array}{c}0.722 \\
(0.417) \\
\end{array}$ & -65.9 & $\begin{array}{c}1,410,000 \\
(21.00)\end{array}$ & -26.2 & $\begin{array}{c}823.6 \\
(0.197)\end{array}$ & +6.8 \\
\hline \multirow{2}{*}{ Grout } & NWG & $\begin{array}{c}1.751 \\
(1.012) \\
\end{array}$ & - & $\begin{array}{c}1,541,578 \\
(23.00)\end{array}$ & - & $\begin{array}{c}738.0 \\
(0.176)\end{array}$ & - \\
\hline & LWG & $\begin{array}{c}0.688 \\
(0.398) \\
\end{array}$ & -60.7 & $\begin{array}{c}1,327,881 \\
(19.81) \\
\end{array}$ & -13.9 & $\begin{array}{c}880.9 \\
(0.211) \\
\end{array}$ & +19.4 \\
\hline \multirow{3}{*}{$\begin{array}{c}\text { Concrete } \\
\text { Masonry Units }\end{array}$} & NWU & $\begin{array}{c}0.995 \\
(0.576) \\
\end{array}$ & - & $\begin{array}{c}1,267,574 \\
(18.91) \\
\end{array}$ & - & $\begin{array}{c}633.1 \\
(0.151) \\
\end{array}$ & - \\
\hline & $\begin{array}{c}\text { LWU, } 1672 \mathrm{~kg} / \mathrm{m}^{3} \\
\left(104.4 \mathrm{lb} / \mathrm{ft}^{3}\right)\end{array}$ & $\begin{array}{c}0.876 \\
(0.507)\end{array}$ & -12.0 & $\begin{array}{c}1,351,493 \\
(20.17)\end{array}$ & +6.6 & $\begin{array}{c}808.2 \\
(0.193)\end{array}$ & +27.7 \\
\hline & $\begin{array}{c}\text { LWU, } 1482 \mathrm{~kg} / \mathrm{m}^{3} \\
\left(92.5 \mathrm{lb} / \mathrm{ft}^{3}\right)\end{array}$ & $\begin{array}{c}0.665 \\
(0.384)\end{array}$ & -33.2 & $\begin{array}{c}1,190,198 \\
(17.76)\end{array}$ & -6.1 & $\begin{array}{c}803.3 \\
(0.192)\end{array}$ & +26.9 \\
\hline
\end{tabular}

For grout mixtures, the lightweight grout (LWG) exhibited a $13.9 \%$ reduction in volumetric heat capacity, with a $19.4 \%$ increase in heat capacity computed by weight. Lightweight CMUs (LWU) of both unit weights exhibited a similar increase in heat capacity by weight, $27.7 \%$ and $26.9 \%$ for the $1672 \mathrm{~kg} / \mathrm{m}^{3}\left(104.4 \mathrm{lb} / \mathrm{ft}^{3}\right) \mathrm{LMU}$ and $1482 \mathrm{~kg} / \mathrm{m}^{3}$ $\left(92.5 \mathrm{lb} / \mathrm{ft}^{3}\right) \mathrm{LMU}$, respectively. When compared to the NWU, tests of the LWU yielded mixed results for volumetric heat capacity, with the $1672 \mathrm{~kg} / \mathrm{m}^{3}\left(104.4 \mathrm{lb} / \mathrm{ft}^{3}\right)$ LWU exhibiting a $6.5 \%$ increase, while the $1482 \mathrm{~kg} / \mathrm{m}^{3}\left(92.5 \mathrm{lb} / \mathrm{ft}^{3}\right) \mathrm{LWU}$ exhibited a $6.1 \%$ decrease. It is suspected that this result is due to potential changes in the mixture proportions used in the two LWUs.

\subsection{Building Energy Simulations-Concrete}

For each simulation in EnergyPlus, the software computed the heating and cooling energy required for each hour of the design day, which is provided in the output file. To facilitate comparison of daily energy requirements for the model as constructed with NWC, SLC, and LWC, the cooling energy required for the typical summer design day and total heating energy required for the typical winter day was totaled. The results are shown for both locations in Table 8.

Table 8. Energy requirements for summer and winter design day for simple concrete structure in two weather scenarios, as predicted using EnergyPlus simulations.

\begin{tabular}{|c|c|c|c|c|c|}
\hline Location/Weather & $\begin{array}{c}\text { Material } \\
\text { Utilized }\end{array}$ & $\begin{array}{l}\text { Total Cooling Energy, } \\
\text { kJ (kWh), for Design } \\
\text { Summer Day }\end{array}$ & $\begin{array}{c}\text { \% Difference, } \\
\text { Compared to } \\
\text { NWC }\end{array}$ & $\begin{array}{l}\text { Total Heating Energy, } \\
\text { kJ (kWh) for Design } \\
\text { Winter Day }\end{array}$ & $\begin{array}{c}\text { \% Difference, } \\
\text { Compared to } \\
\text { NWC }\end{array}$ \\
\hline \multirow{3}{*}{$\begin{array}{l}\text { Chicago, IL } \\
\left(\max 32.8^{\circ} \mathrm{C},\right. \\
\left.\min -21.2^{\circ} \mathrm{C}\right)\end{array}$} & NWC & $193,090(53.3)$ & - & $884,542(245.7)$ & - \\
\hline & SLC & $174,339(48.4)$ & -9.7 & $733,180(203.7)$ & -17.1 \\
\hline & ALC & $135,088(37.5)$ & -30.0 & $535,483(148.7)$ & -39.5 \\
\hline \multirow{3}{*}{$\begin{array}{l}\text { Warmer Location } \\
\quad\left(\max 40^{\circ} \mathrm{C},\right. \\
\left.\min 15^{\circ} \mathrm{C}\right)\end{array}$} & NWC & $266,846(74.1)$ & - & $260,943(72.5)$ & - \\
\hline & SLC & $240,186(66.7)$ & -10.0 & $221,295(61.5)$ & -15.2 \\
\hline & ALC & $185,095,055(51.4)$ & -30.6 & $167,267(46.5)$ & -35.9 \\
\hline
\end{tabular}


Use of the measured thermal properties for normalweight, sand lightweight, and all lightweight mixtures in a simple EnergyPlus building energy simulation model provided insight into the energy savings offered by use of lightweight concrete in structural applications. As can be seen in Table 7 results of the simulations indicated that the SLC and ALC mixtures significantly reduced both the total heating and total cooling energy required to maintain the temperate interior conditions specified in the model. This finding differs from that of a building energy simulation using a residential apartment building model in European weather conditions, in which energy savings were noted for lightweight concrete construction for building heating energy, but not cooling energy [21].

Use of sand lightweight concrete (SLC) in both the Chicago (cooler) and warmer area simulations resulted in prediction of approximately $10 \%$ cooling energy savings and heating energy savings in the range of $15-17 \%$ over NWC construction. The percent savings in heating energy roughly corresponds to the findings of a study by Real et al. [21] using European climate conditions with residential apartment construction.

Use of all lightweight concrete (ALC) in in both the Chicago (cooler) and warmer area simulations resulted in prediction of approximately $30 \%$ cooling energy savings and heating energy savings in the range of $35-40 \%$ over NWC construction. Although this analysis used a single model of a very basic structure that contained many simplifications, this analysis provided insight into the thermal performance advantages that can potentially be offered by lightweight concrete in building envelope and other structural applications.

\subsection{Building Energy Simulations-Masonry}

More advanced models and simulations were used to accurately predict the energy savings associated with lightweight masonry materials that are often viewed as an alternative to conventional light construction framing. Thermal property data and unit weights for lightweight and conventional masonry alternatives were used as alternate construction options in five reference building models. This research focused on five model buildings, in five different climates. Simulations were performed using the source energy assignments from the building reference model (electricity used for cooling energy, electricity or gas used for heating energy). Results from the simulations for each type of reference model building in each of the five selected climate zones are summarized in Tables 9-13. The outdoor air dry bulb temperature for the summer design day and the winter design day at each location is also provided in Tables 9-13, along with the average zone (indoor) air temperature for the summer and winter design days achieved during the simulations.

Of the five models, the alternate construction for the secondary school (Table 9) was the only model to utilize the NWU and grout instead of lightweight materials. Predicted energy saving in heating and cooling for the secondary school ranged from $0.6 \%$ to $1.9 \%$, depending on the location. For each of the five locations, a greater energy savings was predicted for heating (gas) during the winter design day than cooling energy for the summer design day. The greatest net energy savings was for the Chicago location.

For three of the reference models, midrise apartment (Table 10), small hotel (Table 11) and strip mall (Table 12), a lightweight CMU (LWU) and lightweight grout (LWG) were used as the alternate construction to the light gauge framing and wood siding default inputs in the reference models. The midrise apartment and strip mall utilized $1672 \mathrm{~kg} / \mathrm{m}^{3}$ $\left(104.4 \mathrm{lb} / \mathrm{ft}^{3}\right) \mathrm{LWU}$ and lightweight grout in the alternate construction, while the $1482 \mathrm{~kg} / \mathrm{m}^{3}$ $\left(92.5 \mathrm{lb} / \mathrm{ft}^{3}\right) \mathrm{LWU}$ and lightweight grout was utilized in the small hotel. Material type selections for the different structure types were based on the experience of the authors.

Predicted cooling energy savings for the mid-rise apartment (Table 10) on the summer design day ranged from $1.2 \%$ to $1.8 \%$ for all locations. Significant savings in heating energy (electric) on the winter design day in Chicago (6.4\% reduction) and Minneapolis (2.9\% reduction) were predicted. Gas heating energy savings on the design winter day were consistently between $1.2 \%$ and $1.3 \%$ for the four locations in the United States used for the simulations. The heating energy savings for the design winter day for Saudi Arabia was predicted to be $3.2 \%$. 
Table 9. Results for secondary school reference model building energy simulations.

\begin{tabular}{|c|c|c|c|c|c|c|}
\hline & & \multicolumn{2}{|c|}{$\begin{array}{l}\text { Average Zone (Indoor) Air } \\
\text { Temperature, }{ }^{\circ} \mathrm{C}\left({ }^{\circ} \mathrm{F}\right)\end{array}$} & $\begin{array}{l}\text { Cooling: } \\
\text { Electricity, kJ, } \\
(\mathrm{kWh})\end{array}$ & $\begin{array}{l}\text { Heating: } \\
\text { Electricity, kJ } \\
\text { (kWh) }\end{array}$ & $\begin{array}{l}\text { Heating: Gas, kJ } \\
\text { (kWh) }\end{array}$ \\
\hline Location & Exterior Type & $\begin{array}{c}\text { Summer Design } \\
\text { Day }\end{array}$ & $\begin{array}{c}\text { Winter Design } \\
\text { Day }\end{array}$ & $\begin{array}{c}\text { Summer Design } \\
\text { Day }\end{array}$ & $\begin{array}{c}\text { Winter Design } \\
\text { Day }\end{array}$ & $\begin{array}{c}\text { Winter Design } \\
\text { Day }\end{array}$ \\
\hline \multirow{3}{*}{ Chicago } & Typical & \multirow{3}{*}{$\begin{array}{c}23.7 \\
(74.7)\end{array}$} & \multirow{3}{*}{$\begin{array}{l}19.2 \\
(66.6)\end{array}$} & $1,040,022(288.9)$ & \multirow{3}{*}{ - } & $2,162,999(600.8)$ \\
\hline & Alternate & & & $1,027,349(285.4)$ & & $2,130,622(591.8)$ \\
\hline & $\%$ difference & & & -1.2 & & -1.5 \\
\hline \multirow{3}{*}{ Minneapolis } & Typical & \multirow{3}{*}{$\begin{array}{c}23.7 \\
(74.7)\end{array}$} & \multirow{3}{*}{$\begin{array}{l}18.7 \\
(65.7)\end{array}$} & $949,242(263.7)$ & \multirow{3}{*}{-} & $2,454,959(681.9)$ \\
\hline & Alternate & & & $941,040(261.4)$ & & $2,419,955(672.2)$ \\
\hline & $\%$ difference & & & -0.9 & & -1.4 \\
\hline \multirow{3}{*}{ Philadelphia } & Typical & \multirow{3}{*}{$\begin{array}{c}23.8 \\
(74.8)\end{array}$} & \multirow{3}{*}{$\begin{array}{l}19.7 \\
(67.4)\end{array}$} & $1,119,844(311.1)$ & \multirow{3}{*}{ - } & $1,741,960(483.9)$ \\
\hline & Alternate & & & $1,109,046(308.1)$ & & $1,717,401(477.1)$ \\
\hline & $\%$ difference & & & -1.0 & & -1.4 \\
\hline \multirow{3}{*}{ Nashville } & Typical & \multirow{3}{*}{$\begin{array}{c}23.8 \\
(74.8)\end{array}$} & \multirow{3}{*}{$\begin{array}{l}19.8 \\
(67.6)\end{array}$} & $1,140,668(316.9)$ & \multirow{3}{*}{-} & $1,692,692(470.2)$ \\
\hline & Alternate & & & $1,130,840(314.1)$ & & $1,670,366(464.0)$ \\
\hline & $\%$ difference & & & -0.9 & & -1.3 \\
\hline \multirow{3}{*}{ Saudi Arabia } & Typical & \multirow{3}{*}{$\begin{array}{l}24.0 \\
(75.2)\end{array}$} & \multirow{3}{*}{$\begin{array}{l}19.5 \\
(67.1)\end{array}$} & $1,533,811(426.1)$ & \multirow{3}{*}{-} & $829,378(230.3)$ \\
\hline & Alternate & & & $1,154,049(320.6)$ & & $813,945(226.1)$ \\
\hline & $\%$ difference & & & -0.6 & & -1.9 \\
\hline
\end{tabular}

Table 10. Results for midrise apartment building reference model building energy simulations.

\begin{tabular}{|c|c|c|c|c|c|c|}
\hline & & $\begin{array}{r}\text { Average Zo } \\
\text { Tempera }\end{array}$ & $\begin{array}{l}\text { Indoor) Air } \\
{ }^{\circ} \mathrm{C}\left({ }^{\circ} \mathrm{F}\right)\end{array}$ & $\begin{array}{l}\text { Cooling: } \\
\text { Electricity, kJ, } \\
\text { (kWh) }\end{array}$ & $\begin{array}{c}\text { Heating: } \\
\text { Electricity, kJ } \\
\text { (kWh) }\end{array}$ & $\begin{array}{l}\text { Heating: Gas, kJ } \\
\text { (kWh) }\end{array}$ \\
\hline Location & Exterior Type & $\begin{array}{c}\text { Summer Design } \\
\text { Day }\end{array}$ & $\begin{array}{c}\text { Winter Design } \\
\text { Day }\end{array}$ & $\begin{array}{c}\text { Summer Design } \\
\text { Day }\end{array}$ & $\begin{array}{c}\text { Winter Design } \\
\text { Day }\end{array}$ & $\begin{array}{c}\text { Winter Design } \\
\text { Day }\end{array}$ \\
\hline \multirow{3}{*}{ Chicago } & Typical & \multirow{3}{*}{$\begin{array}{c}24.2 \\
(75.5)\end{array}$} & \multirow{3}{*}{$\begin{array}{c}20.7 \\
(69.2)\end{array}$} & $53,212(14.78)$ & $1053(0.292)$ & $473,514(133.2)$ \\
\hline & Alternate & & & $52,304(14.53)$ & $985(0.274)$ & $467,658(129.9)$ \\
\hline & $\%$ difference & & & -1.7 & -6.4 & -1.2 \\
\hline \multirow{3}{*}{ Minneapolis } & Typical & \multirow{3}{*}{$\begin{array}{l}24.2 \\
(75.5)\end{array}$} & \multirow{3}{*}{$\begin{array}{l}20.6 \\
(69.1)\end{array}$} & $54,420(15.12)$ & $2643(0.734)$ & $553,718(153.8)$ \\
\hline & Alternate & & & $53,440(14.84)$ & $2566(0.713)$ & $546,713(151.9)$ \\
\hline & \% difference & & & -1.8 & -2.9 & -1.3 \\
\hline \multirow{3}{*}{ Philadelphia } & Typical & \multirow{3}{*}{$\begin{array}{c}24.2 \\
(75.5)\end{array}$} & \multirow{3}{*}{$\begin{array}{l}20.8 \\
(69.4)\end{array}$} & $64,044(17.78)$ & \multirow{3}{*}{-} & $343,036(95.29)$ \\
\hline & Alternate & & & $63,212(17.56)$ & & 339,819 (94.39) \\
\hline & $\%$ difference & & & -1.3 & & -1.3 \\
\hline \multirow{3}{*}{ Nashville } & Typical & \multirow{3}{*}{$\begin{array}{l}24.2 \\
(75.5)\end{array}$} & \multirow{3}{*}{$\begin{array}{l}20.8 \\
(69.4)\end{array}$} & $65,280(18.13)$ & \multirow{3}{*}{-} & $325,036(90.29)$ \\
\hline & Alternate & & & 64,497 (17.92) & & $320,700(80.08)$ \\
\hline & \% difference & & & -1.2 & & -1.3 \\
\hline \multirow{3}{*}{ Saudi Arabia } & Typical & \multirow{3}{*}{$\begin{array}{c}24.3 \\
(75.5)\end{array}$} & \multirow{3}{*}{$\begin{array}{l}21.0 \\
(69.8)\end{array}$} & $86,436(24.01)$ & \multirow{3}{*}{-} & 81,975 (22.77) \\
\hline & Alternate & & & $85,341(23.71)$ & & $79,380(22.05)$ \\
\hline & $\%$ difference & & & -1.3 & & -3.2 \\
\hline
\end{tabular}


Table 11. Results for small hotel reference model building energy simulations.

\begin{tabular}{|c|c|c|c|c|c|c|}
\hline & & $\begin{array}{r}\text { Average Zor } \\
\text { Tempera }\end{array}$ & $\begin{array}{l}\text { Indoor) Air } \\
{ }^{\circ} \mathrm{C}\left({ }^{\circ} \mathrm{F}\right)\end{array}$ & $\begin{array}{l}\text { Cooling: } \\
\text { Electricity, kJ, } \\
\text { (kWh) }\end{array}$ & $\begin{array}{c}\text { Heating: } \\
\text { Electricity, kJ } \\
\text { (kWh) }\end{array}$ & $\begin{array}{l}\text { Heating: Gas, kJ } \\
\text { (kWh) }\end{array}$ \\
\hline Location & Exterior Type & $\begin{array}{c}\text { Summer Design } \\
\text { Day }\end{array}$ & $\begin{array}{c}\text { Winter Design } \\
\text { Day }\end{array}$ & $\begin{array}{c}\text { Summer Design } \\
\text { Day }\end{array}$ & $\begin{array}{c}\text { Winter Design } \\
\text { Day }\end{array}$ & $\begin{array}{c}\text { Winter Design } \\
\text { Day }\end{array}$ \\
\hline \multirow{3}{*}{ Chicago } & Typical & \multirow{3}{*}{$\begin{array}{c}25.7 \\
(78.3)\end{array}$} & \multirow{3}{*}{$\begin{array}{l}20.3 \\
(68.5)\end{array}$} & $185,842(51.62)$ & $303,065(84.18)$ & $305,329(84.81)$ \\
\hline & Alternate & & & $185,052(51.40)$ & $298,279(82.86)$ & $303,838(84.40)$ \\
\hline & $\%$ difference & & & -0.4 & -1.6 & -0.5 \\
\hline \multirow{3}{*}{ Minneapolis } & Typical & \multirow{3}{*}{$\begin{array}{c}25.9 \\
(78.6)\end{array}$} & \multirow{3}{*}{$\begin{array}{c}20.3 \\
(68.5)\end{array}$} & $181,331(50.37)$ & $352,024(97.78)$ & $355,240(98.68)$ \\
\hline & Alternate & & & $180,309(50.09)$ & $346,554(96.27)$ & $353,529(98.2)$ \\
\hline & $\%$ difference & & & -0.6 & -1.6 & -0.5 \\
\hline \multirow{3}{*}{ Philadelphia } & Typical & \multirow{3}{*}{$\begin{array}{l}26.0 \\
(78.8)\end{array}$} & \multirow{3}{*}{$\begin{array}{c}20.4 \\
(68.7)\end{array}$} & $197,684(54.91)$ & $226,010(62.78)$ & $228,833(63.56)$ \\
\hline & Alternate & & & $195,572(54.33)$ & $212,956(59.15)$ & $227,712(63.25)$ \\
\hline & $\%$ difference & & & -0.5 & -1.8 & -0.5 \\
\hline \multirow{3}{*}{ Nashville } & Typical & \multirow{3}{*}{$\begin{array}{l}26.0 \\
(78.8)\end{array}$} & \multirow{3}{*}{$\begin{array}{c}20.4 \\
(68.7)\end{array}$} & $197,685(54.91)$ & $216,982(60.27)$ & $220,890(61.36)$ \\
\hline & Alternate & & & $196,700(54.64)$ & $212,956(59.15)$ & $219,889(61.08)$ \\
\hline & $\%$ difference & & & -0.5 & -1.9 & -0.5 \\
\hline \multirow{3}{*}{ Saudi Arabia } & Typical & \multirow{3}{*}{$\begin{array}{c}26.4 \\
(79.5)\end{array}$} & \multirow{3}{*}{$\begin{array}{c}20.9 \\
(69.6)\end{array}$} & $221,332(61.48)$ & 81,301 (22.58) & $89,324(24.81)$ \\
\hline & Alternate & & & $219,439(60.96)$ & $79,347(22.04)$ & $89,104(24.75)$ \\
\hline & $\%$ difference & & & -0.9 & -2.4 & -0.2 \\
\hline
\end{tabular}

Table 12. Results for strip mall reference model building energy simulations.

\begin{tabular}{|c|c|c|c|c|c|c|}
\hline & & $\begin{array}{r}\text { Average Zor } \\
\text { Tempera }\end{array}$ & $\begin{array}{l}\text { Indoor) Air } \\
{ }^{\circ} \mathrm{C}\left({ }^{\circ} \mathrm{F}\right)\end{array}$ & $\begin{array}{l}\text { Cooling: } \\
\text { Electricity, kJ, } \\
\text { (kWh) }\end{array}$ & $\begin{array}{c}\text { Heating: } \\
\text { Electricity, kJ } \\
(\mathrm{kWh})\end{array}$ & $\begin{array}{c}\text { Heating: Gas, kJ } \\
\text { (kWh) }\end{array}$ \\
\hline Location & Exterior Type & $\begin{array}{c}\text { Summer Design } \\
\text { Day }\end{array}$ & $\begin{array}{c}\text { Winter Design } \\
\text { Day }\end{array}$ & $\begin{array}{c}\text { Summer Design } \\
\text { Day }\end{array}$ & $\begin{array}{c}\text { Winter Design } \\
\text { Day }\end{array}$ & $\begin{array}{c}\text { Winter Design } \\
\text { Day }\end{array}$ \\
\hline \multirow{3}{*}{ Chicago } & Typical & \multirow{3}{*}{$\begin{array}{c}25.7 \\
(78.3)\end{array}$} & \multirow{3}{*}{$\begin{array}{c}20.3 \\
(68.5)\end{array}$} & 77,668 (21.57) & \multirow{3}{*}{ - } & $761,278(211.5)$ \\
\hline & Alternate & & & $75,344(20.93)$ & & $755,719(209.9)$ \\
\hline & $\%$ difference & & & -3.0 & & -0.7 \\
\hline \multirow{3}{*}{ Minneapolis } & Typical & \multirow{3}{*}{$\begin{array}{c}25.9 \\
(78.6)\end{array}$} & \multirow{3}{*}{$\begin{array}{c}20.3 \\
(68.5)\end{array}$} & $75,832(21.06)$ & \multirow{3}{*}{ - } & $886,312(246.2)$ \\
\hline & Alternate & & & $73,882(20.52)$ & & $878,988(244.2)$ \\
\hline & $\%$ difference & & & -2.6 & & -0.8 \\
\hline \multirow{3}{*}{ Philadelphia } & Typical & \multirow{3}{*}{$\begin{array}{c}26.0 \\
(78.8)\end{array}$} & \multirow{3}{*}{$\begin{array}{c}20.4 \\
(68.7)\end{array}$} & $87,203(24.22)$ & \multirow{3}{*}{ - } & $572,583(159.1)$ \\
\hline & Alternate & & & 85,605 (23.78) & & $567,011(157.5)$ \\
\hline & $\%$ difference & & & -1.8 & & -1.0 \\
\hline \multirow{3}{*}{ Nashville } & Typical & \multirow{3}{*}{$\begin{array}{l}26.0 \\
(78.8)\end{array}$} & \multirow{3}{*}{$\begin{array}{c}20.4 \\
(68.7)\end{array}$} & $89,402(24.83)$ & \multirow{3}{*}{-} & $551,238(153.1)$ \\
\hline & Alternate & & & $87,241(24.23)$ & & $546,486(151.8)$ \\
\hline & $\%$ difference & & & -2.4 & & -0.9 \\
\hline \multirow{3}{*}{ Saudi Arabia } & Typical & \multirow{3}{*}{$\begin{array}{c}26.4 \\
(78.8)\end{array}$} & \multirow{3}{*}{$\begin{array}{c}20.9 \\
(69.6)\end{array}$} & $106,517(29.59)$ & \multirow{3}{*}{ - } & $214,206(59.50)$ \\
\hline & Alternate & & & $107,939(29.98)$ & & $210,082(58.36)$ \\
\hline & $\%$ difference & & & +1.3 & & -1.9 \\
\hline
\end{tabular}


Table 13. Results for supermarket reference model building energy simulations.

\begin{tabular}{|c|c|c|c|c|c|c|}
\hline & & $\begin{array}{r}\text { Average Zor } \\
\text { Tempera }\end{array}$ & $\begin{array}{l}\text { Indoor) Air } \\
{ }^{\circ} \mathrm{C}\left({ }^{\circ} \mathrm{F}\right)\end{array}$ & $\begin{array}{l}\text { Cooling: } \\
\text { Electricity, kJ, } \\
\text { (kWh) }\end{array}$ & $\begin{array}{c}\text { Heating: } \\
\text { Electricity, kJ } \\
\text { (kWh) }\end{array}$ & $\begin{array}{l}\text { Heating: Gas, kJ } \\
(\mathrm{kWh})\end{array}$ \\
\hline Location & Exterior Type & $\begin{array}{c}\text { Summer Design } \\
\text { Day }\end{array}$ & $\begin{array}{c}\text { Winter Design } \\
\text { Day }\end{array}$ & $\begin{array}{c}\text { Summer Design } \\
\text { Day }\end{array}$ & $\begin{array}{c}\text { Winter Design } \\
\text { Day }\end{array}$ & $\begin{array}{c}\text { Winter Design } \\
\text { Day }\end{array}$ \\
\hline \multirow{3}{*}{ Chicago } & Typical & \multirow{3}{*}{$\begin{array}{c}25.1 \\
(77.1)\end{array}$} & \multirow{3}{*}{$\begin{array}{l}19.0 \\
(66.2)\end{array}$} & $99,360(27.60)$ & \multirow{3}{*}{ - } & $1,727,611(479.9)$ \\
\hline & Alternate & & & $98,750(27.43)$ & & $1,730,213(480.6)$ \\
\hline & $\%$ difference & & & -0.6 & & +0.2 \\
\hline \multirow{3}{*}{ Minneapolis } & Typical & \multirow{3}{*}{$\begin{array}{l}25.2 \\
(77.4)\end{array}$} & \multirow{3}{*}{$\begin{array}{l}18.9 \\
(66.0)\end{array}$} & $99,511(27.64)$ & \multirow{3}{*}{-} & $1,960,688(544.6)$ \\
\hline & Alternate & & & $98,861(27.46)$ & & $1,951,609(542.1)$ \\
\hline & $\%$ difference & & & -0.7 & & -0.5 \\
\hline \multirow{3}{*}{ Philadelphia } & Typical & \multirow{3}{*}{$\begin{array}{c}25.3 \\
(77.5)\end{array}$} & \multirow{3}{*}{$\begin{array}{l}19.1 \\
(66.4)\end{array}$} & $115,682(32.13)$ & \multirow{3}{*}{-} & $1,390,072(386.1)$ \\
\hline & Alternate & & & $114,948(31.93)$ & & $1,384,527(384.6)$ \\
\hline & $\%$ difference & & & -0.6 & & -0.4 \\
\hline \multirow{3}{*}{ Nashville } & Typical & \multirow{3}{*}{$\begin{array}{c}25.3 \\
(77.5)\end{array}$} & \multirow{3}{*}{$\begin{array}{l}19.2 \\
(66.6)\end{array}$} & $118,657(32.96)$ & \multirow{3}{*}{ - } & $1,354,454(376.2)$ \\
\hline & Alternate & & & $117,856(32.74)$ & & $1,346,900(374.1)$ \\
\hline & $\%$ difference & & & -0.7 & & -0.6 \\
\hline \multirow{3}{*}{ Saudi Arabia } & Typical & \multirow{3}{*}{$\begin{array}{l}25.5 \\
(77.9)\end{array}$} & \multirow{3}{*}{$\begin{array}{l}19.6 \\
(67.2)\end{array}$} & $203,627(56.56)$ & \multirow{3}{*}{-} & $732,544(203.5)$ \\
\hline & Alternate & & & $202,179(56.16)$ & & 730,315 (202.9) \\
\hline & $\%$ difference & & & -0.7 & & -0.3 \\
\hline
\end{tabular}

Using lightweight masonry materials, the small hotel (Table 11) reference model simulations provided modest cooling energy (electric) savings for the summer design day, ranging from $0.4 \%$ to $0.9 \%$ for each of the five locations. More significant heating energy (electricity) savings were predicted for the winter design day, with reductions of $1.6 \%$ to $1.9 \%$ predicted for the four locations in the United States and a reduction of $2.4 \%$ predicted for the location in Saudi Arabia. If gas heating is utilized, the simulations predicted more modest energy savings for all five locations, $0.5 \%$ for the four locations in the United States and $0.2 \%$ for Saudi Arabia. Of note, precast concrete slabs are often considered for intermediate floors of this type of construction, and future work could consider use of these types of slabs in the energy simulation models.

For the strip mall reference model using lightweight masonry materials (Table 12), building energy simulation results predicted a reduction in cooling energy (electricity) required for the summer design day ranging from 1.8\% (Philadelphia) to 3.0\% (Chicago). The strip mall simulation in Saudi Arabia resulted in a net increase in cooling energy required $(1.3 \%)$, which was one of only two increases in energy use predicted for the lightweight building material alternatives. For all five locations, the building energy simulations predicted a decrease in heating energy (gas) required for the winter design day. More modest energy savings predicted were achieved from this reference model, ranging from $0.7 \%$ to $1.0 \%$ for locations in the United States and a $1.9 \%$ savings predicted for the Saudi Arabia location. These findings are similar to those of a previous study on lightweight masonry use in the strip mall reference model [25], where only modest improvements were exhibited by the lightweight masonry in warmer climates.

The supermarket reference model (Table 13) utilized concrete masonry units with a $2.54 \mathrm{~cm}$ (1 in.) coating of stucco as the default exterior for the reference model. When lightweight masonry was used, predicted cooling energy savings (electricity) for the summer design day ranged from $0.6 \%$ to $0.7 \%$ for all five locations. Heating energy (gas) savings for three of four United States locations (Minneapolis, Philadelphia, Nashville) ranged from $0.4 \%$ to $0.6 \%$. A net increase in heating (gas) energy was predicted for the Chicago location. The simulation performed using the Saudi Arabia weather data predicted a $0.3 \%$ savings in heating (gas) energy. 
A total of 25 building energy simulations were performed demonstrating that in all cases but two, masonry materials should exhibit have lower energy usage requirements for heating and cooling of building models, and consistent energy savings. This is consistent with the findings of other studies showing energy savings of concrete and masonry over other types of construction [22,23], and lightweight concrete masonry over conventional masonry [24,25]. It should be noted that the energy use of each building predicted by the simulations is also influenced by a number of construction-related factors, including fenestration type and area, roofing type, other default materials used in the reference model, and building configuration.

All building energy simulation models, including EnergyPlus, exhibit uncertainty. Uncertainty associated with EnergyPlus has been categorized as the uncertainty of weather data, uncertainty of empirical parameters (such as formulas used to calculated convective flux exchanged with the outside air) and uncertainty of the measured parameters (such as architectural geometries and measured properties used as inputs) [44]. Methods to quantify the uncertainty in EnergyPlus are the subject of recent and ongoing studies [45]. It is noted that although the ranges of uncertainty of the results from this study have not been defined, the results can be viewed as relative comparisons of performance. Future study could include defining uncertainty ranges for these results, and assessing the implications. Additional future studies could include energy performance monitoring/evaluation on actual structures constructed of lightweight concrete and conventional materials.

Other limitations to this study include the use of only a limited number of concrete and mortar mixture proportions and constituent materials. Properties of constituent materials of concrete and masonry mixtures (including cement, fine aggregates, and coarse aggregates) vary by location. Use of different types/sources of constituent materials will affect the thermal and physical properties of the concrete and masonry mixtures. Mixture proportions will also affect the thermal and physical properties of the concrete and masonry materials. In this study, the authors used local materials and mixture proportions typical of conventional concrete and masonry construction in the United States, but it is noted that other materials and mixtures could provide different results.

Only a limited number of building types and climates were included in this study. Models for other types of buildings, or different building configurations and characteristics, could affect the results. Although the models included in EnergyPlus were developed in a manner representing a large portion of the United States building inventory, energy savings for actual structures may vary from the model predictions for a number of reasons ranging from as-built construction to assumptions made in the model.

\section{Conclusions}

Laboratory testing of concrete, grout, and masonry CMU building components provided thermal property test results that are material specific and could be used in a number of applications for design and analysis of structures to assist with weighing of alternatives for building materials and quantification of benefits over the life cycle. Of significance in this study, heat capacity and thermal conductivity tests were performed on bulk specimens (per ASTM C518), without crushing the concrete and compromising air void structure of lightweight fine and coarse aggregate. Lightweight materials showed significant thermal advantages over normalweight control materials, with thermal conductivity tests of concrete mixtures indicating a 33.5\% reduction for sand lightweight concrete (SWC) and a $65.9 \%$ reduction for all lightweight concrete (ALC) over normalweight concrete (NWC). For masonry materials, lightweight grout (LWG) exhibited a 60.7\% reduction in thermal conductivity compared to normalweight grout (NWG), and the lightweight CMU blocks (LWU) of different unit weights had thermal conductivities $12.0 \%$ and $33.2 \%$ lower than the normalweight CMU (NWU). Volumetric heat capacities for sand lightweight (SLC) and all lightweight (ALC) concrete were reduced by $16.8 \%$ and $26.2 \%$ respectively. Volumetric heat capacities for lightweight masonry grout (LWG) and block (LWU) were generally reduced 
as well from those of normalweight masonry grout (NWG) and normalweight masonry units (NWU).

Test results for heat capacity and thermal conductivity for these mixtures reasonably compare to published data, but are specific to the mixtures and offer much higher confidence in their ability to represent the performance of building components utilizing lightweight aggregates in design calculations and in thermal modeling applications, as compared to the large ranges of values currently published in the literature. Significant differences in these measured values indicate that material- and mixture-specific test results could be used by designers to justify the decision to utilize building materials containing lightweight aggregates in new construction.

The accurately measured thermal properties for normalweight, sand lightweight, and all lightweight concrete mixtures were used in a simple EnergyPlus building energy simulation model to demonstrate the potential energy savings offered by use of lightweight concrete in structural applications. Use of sand lightweight concrete (SLC) resulted in prediction of $15-17 \%$ heating energy savings and 10\% cooling energy savings. Use of all lightweight concrete (ALC) resulted in prediction of approximately $35-40 \%$ heating energy savings and 30\% cooling energy savings over the building constructed with normalweight concrete (NWC). These findings indicated that use of these materials will significantly affect the energy performance of a building, and if building energy simulations are utilized in the design process, the material- and mixture-specific thermal properties should be obtained and utilized.

More advanced models and simulations were used to accurately predict the energy savings associated with lightweight masonry materials that are often viewed as an alternative to conventional light construction framing due to economic factors and design considerations/preferences. A total of 25 building energy simulations were performed demonstrating that in all cases but two, masonry materials typically have lower energy usage requirements for heating and cooling of building models compared to conventional light frame construction, and consistent energy savings. Predicted energy saving in heating and cooling for the five models ranged from $0.2 \%$ to $6.4 \%$, depending on the building configuration, climatic and weather conditions, and materials used. These findings align with previous studies that show energy and energy cost savings for concrete and masonry materials over other types of exterior construction [21-25]. Modest energy savings were found for both heating energy and cooling energy, contrary to some other studies.

Author Contributions: Conceptualization, T.L.C., J.L. and C.F.; methodology, T.L.C., J.G., C.F. and J.W.; software, T.L.C. and J.G.; formal analysis, T.L.C., J.G. and R.W.C.; investigation, T.L.C., C.F. and J.L.; resources, C.F. and J.W.; data curation, T.L.C.; writing-original draft preparation, T.L.C., J.G. and R.W.C.; writing-review and editing, R.W.C., J.L., C.F. and J.W.; supervision, T.L.C.; project administration, T.L.C.; funding acquisition, T.L.C. and J.W. All authors have read and agreed to the published version of the manuscript.

Funding: This research was funded by Stalite.

Institutional Review Board Statement: Not applicable.

Informed Consent Statement: Not applicable.

Data Availability Statement: Data is contained within the article. Additional supporting data presented in this study are available on request from the corresponding author.

Conflicts of Interest: The authors declare no conflict of interest.

\section{References}

1. ACI Committee 213. Guide for Structural Lightweight-Aggregate Concrete (ACI 213-R14); American Concrete Institute: Farmington Hills, MI, USA, 2014; p. 59.

2. ASTM. Standard Specification for Lightweight Aggregates for Structural Concrete; ASTM C330-05; American Society for Testing and Materials: West Conshohocken, PA, USA, 2019. 
3. Holm, T.A.; Ries, J. Chapter 2: Manufacturing of ESCS Lightweight Aggregate. In Reference Manual for the Properties and Applications of Expanded Shale, Clay and Slate Lightweight Aggregate; Expanded Shale; Clay and Slate Institute: Chicago, IL, USA, 2007 ; p. 18.

4. Kim, K.-H.; Jeon, S.-E.; Kim, J.-K.; Yang, S. An Exper-imental Study on Thermal Conductivity of Concrete. Cem. Concr. Res. 2003, 33, 363-371. [CrossRef]

5. Vangeem, M.G.; Holm, T.A.; Reis, J.P. Optimal Thermal Mass and R-Value in Concrete. In Proceedings of the First International Conference on Concrete Sustainability, Tokyo, Japan, 27-29 May 2013; pp. 411-418.

6. Tatro, S.B. Thermal Properties. In Significance of Tests and Properties of Concrete and Concrete-Making Materials; STP 169D; ASTM International: West Conshohocken, PA, USA, 2006; pp. 226-237.

7. ACI Committee 122. Guide to Thermal Properties of Concrete and Masonry Systems (ACI 122R-14); American Concrete Institute: Farmington Hills, MI, USA, 2014; p. 21.

8. Valore, R.C. Calculation of U-Values of Hollow Concrete Masonry. Concr. Int. 1980, 2, 40-63.

9. American Society of Heating, Refrigerating and Air-Conditioning Engineers. 2013 Handbook: Fundamentals; ASHRAE: Atlanta, GA, USA, 2013; p. 1108.

10. Valore, R.C. Thermophysical Properties of Masonry and its Constituents, Parts I and II; International Masonry Institute: Washington, DC, USA, 1988.

11. Cavalline, T.L.; Castrodale, R.W.; Freeman, C.; Wall, J. Impact of Lightweight Aggregate on Concrete Thermal Properties. ACI Mater. J. 2017, 114, 945-956. [CrossRef]

12. ASTM. Standard Test Method for Steady-State Heat Flux Measurements and Thermal Transmission Properties by Means of the GuardedHot-Plate Apparatus; ASTM C177-19; American Society for Testing and Materials: West Conshohocken, PA, USA, 2019.

13. ASTM. Standard Test Method for Thermal Performance of Building Materials and Envelope Assemblies by Means of a Hot Box Apparatus; ASTM C1363-19; American Society for Testing and Materials: West Conshohocken, PA, USA, 2019.

14. Whiting, D.; Litvin, A.; Goodwin, S.E. Specific Heat of Selected Concretes. ACI J. Proc. 1978, 75, $299-305$.

15. Castrodale, R.W.; Cavalline, T.L. Thermal Properties of Lightweight Concrete and Their Impact on Bridge Design. In Proceedings of the 2017 Precast Concrete Institute (PCI) Convention and National Bridge Conference, Cleveland, OH, USA, 28 February-4 March 2017.

16. Kibert, C.J. Sustainable Construction: Green Building Design and Delivery, 3rd ed.; John Wiley \& Sons: Hoboken, NJ, USA, 2016.

17. Energy Plus. Department of Energy, Office of Energy Efficiency \& Renewable Energy. Available online: https:/ / energyplus.net/ (accessed on 15 December 2020).

18. Crawley, D.B.; Lawrie, L.K.; Pedersen, C.O.; Liesen, R.J.; Fisher, D.E.; Strand, R.K.; Taylor, R.D.; Winkelmann, R.C.; Buhl, W.F.; Huang, Y.J.; et al. ENERGYPLUS, A New-Generation Building Energy Simulation Program. Proc. Build. Simul. 1999, 1, 81-88. [CrossRef]

19. Fumo, N.; Mago, P.; Luck, R. Methodology to estimate building energy consumption using EnergyPlus benchmark models. Energy Build. 2010, 42, 2331-2337. [CrossRef]

20. University of Illinois and University of California, Berkeley. Getting Started with EnergyPlus, Basic Concepts Manual-Essential Information You Need About Running Energy Plus. EnergyPlus Documentation v8.4.0. Available online: https:/ / energyplus. net/sites/all/modules/custom/nrel_custom/pdfs/pdfs_v8.4.0/GettingStarted.pdf (accessed on 15 July 2020).

21. Real, S.; Gomes, M.G.; Rodrigues, A.M.; Bogas, J.A. Contribution of structural lightweight aggregate concrete to the reduction of thermal bridging effect in buildings. Constr. Build. Mater. 2016, 121, 460-470. [CrossRef]

22. Roberz, F.; Loonen, R.C.G.M.; Hoes, P.; Hensen, J.L.M. Ultra-lightweight concrete: Energy and comfort performance evaluation in relation to buildings with low and high thermal mass. Energy Build. 2017, 138, 432-442. [CrossRef]

23. Marceau, M.L.; Van Geem, M.G. Modeling Energy Performance of Concrete Buildings for LEED-NC, V. 2.2, Energy and Atmosphere Credit 1; PCA R\&D Serial No. 2880a; Portland Cement Association: Skokie, IL, USA, 2006.

24. Sousa, H.P.; Sousa, R.M.; Silva, L.C.; Sousa, G.N. Contribution of Numerical Thermal Simulation of Masonry to the Global Objective of Buildings Energy Efficiency. In Proceedings of the ECCOMAS Congress 2016, VII European Congress on Computational Methods in Applied Sciences and Engineering, Crete Island, Greece, 5-10 June 2016.

25. Nicholas, T.; Cavalline, T.; Johnson, D.; Laney, M. Thermal Performance of a Recycled Aggregate Utilizing Building Energy Simulation Programs. In Proceedings of the 2016 IAJC-ISAM International Conference, Orlando, FL, USA, 6-8 November 2016.

26. ASTM. Standard Specification for Concrete Aggregates; ASTM C33/C33M-18; American Society for Testing and Materials: West Conshohocken, PA, USA, 2018.

27. AASHTO. Standard Specification for Sizes of Aggregates for Road and Bridge Construction; American Association of State Highway and Transportation Officials: Washington, DC, USA, 2005.

28. AASHTO. Standard Specification for Lightweight Aggregatges for Structural Concrete; AASHTO M195; American Association of State Highway and Transportation Officials: Washington, DC, USA, 2019.

29. North Carolina Department of Transportation. Standard Specifications for Roads and Structures; North Carolina Department of Transportation: Raleigh, NC, USA, 2018.

30. ASTM. Standard Specification for Portland Cement; ASTM C150 / C150M-20; American Society for Testing and Materials: West Conshohocken, PA, USA, 2020.

31. ASTM. Standard Specification for Concrete Made by Volumetric Bathing and Continuous Mixing; ASTM C685/C685M-17; American Society for Testing and Materials: West Conshohocken, PA, USA, 2017. 
32. ASTM. Standard Practice for Making and Curing Concrete Test Specimens in the Laboratory; ASTM C192/C192M-18; American Society for Testing and Materials: West Conshohocken, PA, USA, 2018.

33. ASTM. Standard Test Method for Air Content of Freshly Mixed Concrete by the Pressure Method; ASTM C231/C231M-17a; American Society for Testing and Materials: West Conshohocken, PA, USA, 2017.

34. ASTM. Standard Test Method for Air Content of Freshly Mixed Concrete by the Volumetric Method; ASTM C173/C173M-16; American Society for Testing and Materials: West Conshohocken, PA, USA, 2016.

35. ASTM. Standard Test Method for Slump of Hydraulic-Cement Concrete; ASTM C143/C143M-20; American Society for Testing and Materials: West Conshohocken, PA, USA, 2020.

36. ASTM. Standard Test Method for Density (Unit Weight), Yield, and Air Content (Gravimetric) of Concrete; ASTM C138/C138M-17a; American Society for Testing and Materials: West Conshohocken, PA, USA, 2017.

37. ASTM. Standard Test Method for Compressive Strength of Cylindrical Concrete Specimens; ASTM C39/C39M-20; American Society for Testing and Materials: West Conshohocken, PA, USA, 2020.

38. ASTM. Standard Test Method for Steady-State Thermal Transmission Properties by Means of the Heat Flow Meter Apparatus; ASTM C518-17; American Society for Testing and Materials: West Conshohocken, PA, USA, 2017.

39. ASTM. Standard Specification for Mixing Rooms, Moist Cabinets, Moist Rooms, and Water Storage Tanks Used in the Testing of Hydraulic Cements and Concretes; ASTM C511-19; American Society for Testing and Materials: West Conshohocken, PA, USA, 2019.

40. Thornton, B.A.; Halverson, M.A.; Myer, M.; Loper, S.A.; Richman, E.E.; Elliott, D.B.; Mendon, V.; Rosenburg, M.I. National CostEffectiveness of ASHRAE Standard 90.1-2010 Compared to ASHRAE Standard 90.1-2007; Pacific Northwest National Lab: Richland, WA, USA, 2013.

41. Field, K.; Deru, M.; Studer, D. Using DOE Commercial Reference Buildings for Simulation Studies. In Proceedings of the SimBuild 2010, New York, NY, USA, 11-13 August 2010. Conference Paper NREL/CP-550-48588.

42. Commercial Reference Buildings. Department of Energy, Office of Energy Efficiency \& Renewable Energy. Available online: https: / / www.energy.gov / eere/buildings/commercial-reference-buildings (accessed on 15 July 2020).

43. Energy Plus Weather Data. Department of Energy, Office of Energy Efficiency \& Renewable Energy. Available online: https: / / energyplus.net/weather (accessed on 15 July 2020).

44. Ding, Y.; Shen, Y.; Wang, J.; Shi, X. Uncertainty Sources and Calculation Approaches for Building Energy Simulation Models. Energy Procedia 2015, 78, 2566-2571. [CrossRef]

45. Validation and Uncertainty Characterization for Energy Simulation. Department of Energy, Office of Energy Efficiency \& Renewable Energy. Available online: https://www.energy.gov/eere/buildings/downloads/validation-and-uncertaintycharacterization-energy-simulation (accessed on 15 January 2021). 